\title{
O ENSAIO LITERÁRIO NO BRASIL ${ }^{1}$
}

\author{
Alexandre Eulálio
}

\section{CAMPO E CONTRACAMPO}

Cercado por quase todos os lados pela atividade interessada, o ensaio literário enquanto ensaio e enquanto literário é uma península estética de maré muito variável. Na baixa, a sua superfície caminha em direção das áreas vizinhas, muitas vezes anexando, quase sem o perceber, vastas regiōes limílrofes à sua própria.

Daf a necessidade de restringir, ainda que de modo arlificial. essa movediça ordem de dissertação, que a todo momento confina com a filosofia e a política. a novela e o documento, dentro de um campo que compreende tanto a erudição pura quanto o apontamento ligeiro do fait divers. Este o motivo de, nas páginas que se seguem, limitarmos a apresentação do ensaísmo brasileiro, nos espichados e arbitrários anos que vão de 1750 a 1950, no seu sentido geral de livre comentário estético, expresso dentro de um critério mínimo de prosa literária cultivada. E que desse modo compreenda as considerações críticas e interpretativas sobre a história da cultura nacional, na sua esfera própria de "belas-letras" quanto a variaçăo mais ou menos livre, séria ou jocosa, sobre sentimentos, fátos, pessoas, sucessos.

Examinados apenas nas suas modalidades formais ou temáticas, indiferentemente da extensão de artigos de jornal ou in folio, tentamos sintetizar aqui a evolução do ensásmo brasileiro nas três maneiras que nele

1 Premiaclo há mais de trinta anos, este ensnio de Alexandre Eulállo apresenta anotaçđes marginals, indicaçies de tópicose parn desenvolvimento e variantes de palavras em número suficente parn sugerir que era de se espernr umn segundn versfo definitiva. Como nâo fol dado an autor realizá-la, optnıno por publicar também suns anotaçèes - em Apénclice e organizadas e.n ordem allahélica para dar a conhecer este aspecto dos bastidores de seu trabalho ensaistico. (N.P.) 

(17):9-54, 1989.

parecem fundamentais, a saber: (a) o ensaio subjetivo fantasioso, pessoal, egotista - chamado em inglês de faniliar essay: um dos raros gêneros que, talvez por estar ligado de modo indissolúvel à imprensa periódica, pão nosso de cada dia, goza de idéntico favor do público desde o Pré-romantismo; (b) o ensaio crítico enquanto discussão estética do fato literário, sob a forma de estudos, análises, notícias, resenhas, recensōes; e ainda o de idéias gerais, enquanto nele for voluntária, evidente e predominante, a expressão literária, "artística"; (c) o ensaio descritivo, narrativo e interpretativo de intenção estética, cuja objetividade expositiva afaste-o da profissão personalista do gênero: descrição de costumes e tipos, "memórias sentimentais", etc. Naturalmente não devem ser esquecidas outras variantes consideradas ensaísticas, sejam aforismas, máximas, provérbios, "as bases do ensaio"2; assim como polêmicas, sátiras, cartas-abertas, panfletos, e mais, que ainda se caracterizem corno reflexão de índole mais ou menos remotamente moral, e composição literária próprias ao ensaio.

Talvez cause espécie esse reunir sob a mesma designação geral das diversas variedades de prosa enumeradas acima. Embora definido na edição original do Dicionário de Morais como "Escrito em que se examina alguma coisa" talvez repugnasse ao espírito da língua essa identificação indeterminada de ensaio segundo a acepção mais propriamente inglesa. pouco corrente entre nós. Tanto mais que em nossa linguagem ensaio sempre quis significar a designação modesta para tratado, conforme é fácil verificar através dos exemplos que vếm do século XVIII para o XIX. Ainda hoje empregamo-lo. não sem algum hesitar, como sinônimo imperfeito de estudo.

Mais forte do que tal costume em aberto é, contudo, a acepção mais estritamente literária da voz, geralmente aceita como transitando de Montaigne para os folhetinistas ingleses, e destes universalizando-se nas demais literaluras. Ainda que com a tendência de fixar o essay na acepção subjetiva de peça fantasiosa e livre de pecuena extensão, a partir da decisiva celebridade das gazetas selecentistas, não há maiores motivos para que não seja estendida lambém ao Português essa acepção, lado a lado com as outrass que já designam

WITIINGTON, Roberi. Essay, verbete da Encyclopordia Americama. "One root of the essay is found in gnomic or aphoriristic snyings like those in the Book of Proverhs. Ecclesiates and Paclesiasticus, or collections of such maxims. Marcus Aurelius Anloninus (121-180 AD) wrote his Meditations maintianing an earlier tradition which is represented by the Marims (166,3) of the Disc de la Rechefoucauld (1613-1680) and the aphorisms of Benjamin Frankltn in his Poor

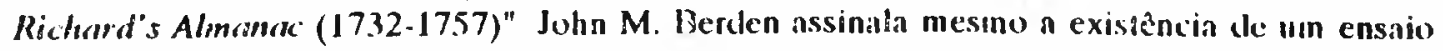
proprinmente aforistico, peculiar à mentalidade conceplisla que tianco marcoun uma dias vertentes do genêro: "A series of aphoristic sentences bound logether by their bearing on 1 common lopic, such as Hacon's essays and, to a lesser Jegree, limerson's. Ilere, in spile of gevmelry, the part may he greater than the whole, for the inclividual sentences are suggestive out of their

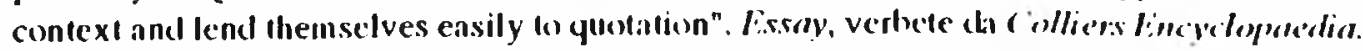



$(17): 9-54,1989$.

esse gênero essencialmente flexível. Não é menos translalo o nome de crônica que, desde fins do século passado, chamamos à variante coloquial do gênero.

Acolhendo assim debaixo do nome de ensaio lanto composiçôes longas, à maneira do tralado antigo, como as peças curtas e ligei ras, interessou-nos antes de tudo o critério estilístico da prosa literária de não-ficção, que tornaria possível estudar, no seu conjunto, manifestações diferentemente aparentadas entre si. Que eram, em última instância, os mesmos escritos artísticos "em que se examina alguma coisa, como o ensaiador os metaes" registrados pelo vel ho dicionarista. Com humour e estilo, o argentino José Edmundo Clemente (e assim se inscrevia na vertente conceitual do gênero) já havia dito com visível impertinência: "Definir el ensayo es una tarea superior a la ambición de escribirlo". (a)

Colocado diante do complexo programa de sintetizar, em rápido conspecto, o ensaio literário no Brasil, o autor tentou, sempre que possível, caracterizar concrelamente a visão do conjunto e do pormenor.

\section{ENSAIO \& ENSAIO}

Até primórdios do Século XIX, a prosa de não-fieção em nossa língua ao deixar de ser científica é quase só mística, didática ou acadêmica. Se se excetua a figura por todos os tílulos notável de Dom Francisco Manuel de Melo, precursor de um gênero que também se acusa em obras diferentes entre elas como a maquiavélica Arle de Furtar ou os escritos vários dessa boa ligura que é o Cavaleiro de Oliveira, o ensaio em Porlugal existe apenas na acepçāo de monografia especializadda, significando memória maciça, ou observações, considerações \& notícias cruditas. ${ }^{\text {(b) }}$ No sentido de livre comentário de idéas gerais, no de discussão ora pessoal ora objetiva de um determinado tema, conforme já vinha se generalizando nos grandes centros europeus, nos meados do Século XVIII, escapa quase de todo da área portuguesa; será necessário rastrear os bons autores para neles encontrar lais exemplos de índole ensatstica ${ }^{(c)}$. O único gazelear permitido, e isso porque aristocrático, ciceroniano, intemporal, é a publicação em volume de cartas literárias, que o autor, numa tentaliva de discreta espontaneidade antiga, rotulará de fiamiliares. Numa época de minudente formalismo essas constiluáam pelo menos um convile ao cotidiano e o seu quase pastoral desalinho. Com a vantagem edificante de ainda pertencerem a literalura "de exemplo" pelas liçóes de bem viver que sempre conlinhaım" (d). 

(17):9-54, 1989.

\section{IMPRENSA, DESPOTISMO, LUZES}

Fora da folha oficial, laconico diário do governo (que tem início em 1715 e mesmo assim interrompe-se de 1762 a $1778^{3}$ ), lodas as tentativas de periodismo sáo efémeras em Portugal. O espírito cosmopolita do fidalgo douto e do clérigo sabedor do Seiscentos, atrofiam-se aos poucos nos seus sucessores burgueses do século das Luzes, sem o meio próprio de expressão daqueles, que pretendem alcançar um público vasto. Só a imprensa não limitaria a uma pequena parcela da nobreza, do clero e do terceiro estado mais próspero a divulgaçāo da cultura, até então confinada à livraria do erudito ciumento.

"Luz para todos": 0 ape lo a uma geral concidadania do espírito contudo está vedado aos súditos do velho reino ocidental. O espírito do século deve ainda dividir-se, em aparente síntese, entre os seus extremos: a atmosfera da Coimbra reformada, as salas severas da Real Academia das Ciências, ou entâo o chá e viola dos salōes literários. a instabilidade de Arcádias e outras sociedades letradas, onde o magistério estético de um membro mais proeminente logo se transformava em irrespirável ditadura. Um meio-termo ao jeito dos folhetinistas ingleses, senhores de exercerem, ao lado de amena crítica de costumes, o alto sentido da divulgação ilustrada, ainda parece inalcançável aos portugueses, que não dispõem da imprensa, o seu natural veículo de expressão. O ensaiomoderno surgirá mais tarde exalamente do compromisso entre a já então inadiável necessidade de periodismo e livre-juízo. Consequiência imediata desse espírito reivindicativo, uma das suas armas imprescindíveis será a sátira.

\section{OCULTAS PRAIAS ESCONDIDAS}

Província ultramarina, desde o Século XVIII a América Portuguesa participava da villa culta da Metrópole através de minguada mas aluante Gração da sua elite. Diverso do espírilo imperial espanhol. que não havia temido espalhar universidades crioulas do México a Chuquisaca, concentrara-se no coeso unitarismo conimbricense o sentido português de pátria-grande. com o qual se pretendia modelar o espírito das melhores capacidades de aquém e além-mar. A "lusa Alenas" era essa forma única que daria a indispensável concepçño de Reino às futuras classes dirigentes. Isso ao mesmo tempo que selectonava para o serviço imediato de EI-Rei. das cinco partidas do mundo onde

3 Cf. Rucha Marlins. Pequena Historia da Imprensa Porruguesa Itston. Inquérito, 1941. (C'adernos Inyuéritu ( $X V$ ) pp. 26, 28, .3) 
(17):9-54, 1989.

se encontravam as colônias, a flor de uma burocracia indispensável à administração e ao poderio do Trono Fidelíssimo.

Era violento o desencontro desse ideal centralizador com a realidade na qual iam esbarrar os portugueses no Além-mar. Tanto os mazombos veteranos de Coimbra, que voltavam às capitanias originárias, quanto os funcionários de segunda ordem, estabelecidos de modo definitivo nos vice-reinados de mundo afora, entravam em violento conflito interior. Divididos entre o sentimento de legitimidade e a sensação de inconfidência, esta última começava a se acusar tanto pelo bairrismo crescente como pelo vislumbre até então desconhecido ${ }^{(e)}$ do que era injustiça. Não terá sido esse dilaceramento ainda cheio de perplexidade uma das menores causas do espírito reivindicativo que, no campo específico do saber, faria esses esquecidos órfãos da cultura "renascerem" em transitórias companhias académicas. Na sua ufania ingênua, não pretendiam eles menos do que fazer significar, em seu verdadeiro valor intelectual, essas desprezadas finisterras da cultura. Com o tempo, tais grêmios inofensivos, seguindo natural evolução do sentido da própria valia, contaminam-se até de inconformismo político, e já não dispensam o livre-exame como a base da inteligência: é este o itinerário que vai dos Felizes de Gomes Freire à Sociedade Literária do Senhor Dom Luís de Vasconcelos.

\section{INQUIETAÇÃO, LIBERDADE: A IMPRENSA}

A inauguração, às vésperas da Independência, do processo do jornalismo político e participante, que se organiza, em plano inclinado, com intuito nitidamente orientador da opinião pública e partidária, fora precedida por inquietude espiritual de definida expressão ideológica. Todo o período que vai de 1808 a 1821 é uma espécie de ciclo preparatório em que, com a indispensável licença régia, ensaiamos as nossas forças, para futuro próximo.

Daf a importância de perí́dicos como "O Patriota", folha literária, política e mercantil, coletanea heterogênea de trabalhos especializados nos diversos ramos do conhecimento, inclusive peças literárias, e se apresenta como a primeira publicação no gênero impressa no Brasil, se se excetuam a oficiosa "Gazeta do Rio de Janeiro", prolongamento do diário de governo de Lisboa, e o baiano, "As Variedades ou Ensaios de Literatura", de Domingos Bivar, heróico e efêmero ${ }^{4}$ Este esboço de imprensa cumpre o seu fim com muito brio. Antes de tudo vinha desafogar uma elite cultural cuja necessidade de

4 (ASTE10, José Aderalck). "Pródromos do Romantismo" em A Literatura no Brasil, vol. I, lomo 2. pp. 638-640. Rio de Janeiro. Editora Sul-Americana, 1956. 

(17):9-54, 1989.

comunicação no campo do conhecimento não podia mais ser recalcada. Por isso representa como que o anúncio vivo de uma época cheia de esperança, e chegou mesmo a encarnar a promessa de um trabalho intelectual em comum, uma espécie de ilusão universitária acariciada pelos sequiosos letrados locais.

\section{HIPÓLITO DA COSTA}

Seria já alguma coisa, onde até então nada havia sido permitido, mas ainda não era, nem de longe, a imprensa entendida conforme as aspirações dos liberais. Da autêntica liberdade de expressão só poderia fruir, nesse período, um exilado voluntário que seguidas perseguições fizeram se recolhesse na tolerante Inglaterra. Assim, ao aparecimento do "Correio Brasiliense", a gazeta londrina de Hipólito da Costa, devemos não só a primeira livre expressão de pontos de vista ideológicos, como a própria origem do ensaio em alto nível intelectual. Para isso é bem possível que contribuísse de maneira decisiva a presença do autor na capital inglesa, onde encontrava a melhor tradição tanto política quanto literária do gênero.

Com o fito de convencer e fazer agir - portanto sob o duplo signo do imediatismo e do pragmatismo -, Hipólito inaugurava com extraordinário valor um púlpito civil, se quase sempre de alcance político, não descuidando nunca do aspecto expressivo. Não deixa dúvida disso o próprio segundo tílulo do "Correio", "Armazém Literário". Armazém traduzia ao pé da letra o magazine britânico, com idêntica pretensão à multiplicidade, e ainda que Literatura tivesse então o sentido genérico de Saber, não o específico de Belas-Letras, a formação, o cultivo, o bom gosto do redator não o faziam um só instante perder de vista o ideal letrado da prosa tersa e clara na qual expunha os seus pontes de vista. O empuxe de Hipólito da Costa seria definitivo, e o seu exemplo, logo que possível, seguido de perto.

\section{O "CORREIO BRASILIENSE"}

"Escola das necessidades e dos anseios da pátria nascente", conforme o definiu Otávio Tarquínio de Sousa, o "Correio Brasiliense" teve ação decisiva ao irromper num meio adormecido que bruscamente se aparelhava para servir de sede da Monarquia. E tanto maior era sua repercussão, pela absoluta liberdade de crítica dispunha o publicista. Com as imunidades que o

5 "O meio intelectual na época di Independéncia" em Fatos e personagens em torno de um regime. Rio de Janeiro, José Olimpto, 1957, p. 23 (Histórin dos Fundadores do Império do Brasil 9). 
(17):9-54, 1989.

estar em Londres the propiciava, ele podia dar-se ao luxo inaudito de dispensar até todo e qualquer tom áulico.

No ocaso do absolutismo contraditoriamente iluminado do neto de Dom José, a missão da fol ha de Hipólito é antes de tudo civilizadora. Naquele meio em que era vedado transmitir quaisquer idéias novas, a influência do "Brasiliense" será impressionante. Se oficialmente tem a circulação proibida, o próprio Regente, Rei pouco depois, não deixa de o ler para pôr-se a par de juízos e censuras do periódico; a isso seria talvez induzido pelos seus ministros mais progressistas, que vêem na providencial língua solta desse conselheiro extranumerário, precioso auxiliar da própria política. "Infatigável no seu amor e na lucidez da sua crítica" ${ }^{6}$, o efeito do pensamento e da linguagem de Hipólito reflete-se de imediato em todos os meios. Dará elevação e estilo ao ensaŕsmo político participante que vai nascer conformando um ideal de prosa direta, de justo comentário, de exposição ponderada e análise objetiva. Resumia ao mesmo tempo, na folha, as diversas possibilidades desse gênero até então inédito, e que Hipólito inaugurava num sentido moderno dele.

\section{O ENSAÍSTA HIPÓLITO DA COSTA}

Não poderia ser de outro modo: essa tribuna que ocupa anos a fio com sempre novo ardor, ofereceu ao editor do "Brasiliense" a oportunidade única de se exprimir nos mais diferentes tons, sobre os assuntos mais diversos, ainda que o interesse precípuo dele não se afaste nunca do pensamento social. Cabe-lhe de direito essa paternidade do nosso ensaismo: ele o incorpora, nas próprias origens, a uma compreensão totalizante da cultura, da qual participa de modo crítico em diversas esferas do conhecimento. Encara também o nosso conjunto nacional - a vasta comunidade luso-brasileira, um todo indissolúvel para a sua visão iluminada como parte integrante da cultura universal. Escrevia da Inglaterra para o Brasil, conhecendo com justeza nossos problemas, e ao mesmo tempo, podendo imaginar um pouco daquilo que prometia a revolução industrial, cujo desenrolar tinha a oportunidade de assistir na própria origem. Considerava portanto a Literatura de um ponto de vista largamente pragmático, indesligável do aspecto empenhado moral, social, filosófico, político -, mas não lhe diminula a importância própria de arte de escrever e comunicar. Por motivo de coerência interior desejava-a participante, influindo de modo decisivo, para o advento do Progresso. O "Armazém Literário" foi assim uma ativa enciclopédia brasiliense que, sem fazer concessões, preencheu os fins de divulgaçáo da doutrina liberal. 

(17):9-.54, 1989.

\section{JORNALISMO DA INDEPENDENCIA}

Os seus sucessores, até chegarem ao equilíbrio intransigente de um Evaristo da Veiga (a "Aurora Fluminense" é de 1827) atravessarão, ao sabor de todas paixōes políticas, a franquia desmedida de uma liberdade de imprensa que vinha aproveitar a una coletividade ainda na véspera sem a mesma permissão para existir como corpo opinativo. Ao sabor do talento de cada um, varia entre todos os níveis daquilo que Antonio Candido chamou de jornalismo

de ensaio, de artigo e de paníleto ${ }^{7}$ Nessa imprensa o ensaio o jornalismo de ensaio - abrirá dificultosamente um caminho de cultura. Mas pela própria índole de argumento atuante, é gênero que havia de se destacar progressivamente, até aí, de uma vez por todas, individualizar-se como instituiçấo literária, sempre mais vizinho do seu sentido próprio de reflexão.

Já foi assinalado acima que o ensalsmo monográfico, tanto o de teor científico como aquele atinente a tal ou qual especialidade, pela própria essência discursiva era de teor universitário e elocução acadêmica. Apenas com o aparecimento da imprensa periódica pôde o gênero começar a ter existência e dirigir-se em todos os sentidos.

A reflexão de propósito moral, tocada de Iluminismo, propagara-se através daquilo que a Inquisição, "com a sua linguagem mística" ${ }^{8}$ chałiava de lepra hebraica isto é, a contaminação das idéias francesas. As máximas e reflexões ao gos to dos moralistas do Século XVII e XVIII para os seus leitores coloniais a diferença não seria grande.

\section{EPÍSTOLAS A MRZERUMO}

Desde então propõe-se ela ao modo de discursos éticos, muito en favor ro perfodo; ao jeito presígioso de correspondência pedagégica, perfaz o ro!eiro tibpico da educaçr̃o ideal. Expor a vagas personagens de uma FÉria de exemiñ lo e de anagrama os princípios ideais da nova sociedade regida pela Razāo, é uma das fi nas regras do jogo, e esse, pois, o fim altamente didático das epistolas de Sousa Caldas. Datadas de 1812 e 1813 e dirigidas ao absirato lrzerumo, tratam de espectos cruciàs da questão máxima das Luzes: Liberdnde, toierârcia, elucą̧ã̃o, convívio social. Mesmo reduzidas aos poucos exempios que até nós

7 Foranasãa da Literatura Brasileira. Vol. I, p. 243. Sño Paulo, Martins, 1959.

8 S.4jJTOS, loaguim Felfcio dor. Memórias do Distriso Diamantino. Rio de Janejro, Ediçbes O Cruzeiro, 1956 ( $3^{\circ}$ celiç̧o). 
chegaram - cinco em meia centena, dos quais apenas dois publicados até 1964 dão a boa medida do talento do autor. Peças de raro equilíbrio, com elas Sousa Caldas inaugurava uma tradição do ensaio doutrinário de rara eficácia expressiva, que só encontraria paralelo durante o Século XIX brasileiro em obras indiferentes ao propósito beletrista.

\section{FREI CANECA}

Debaixo da mesma ficção de correspondência, mas no pólo oposto pelo tom que adota, "expressão coerente dum caráter, um ponto de vista e um estilo", no dizer de estudioso ${ }^{9}$, estão as polêmicas C'artas de Pítia a Damão (1823), de Frei Caneca. Ardentes, pessoais, desabridas, dizendo nomes aos bois e ao carreiro, com veemência característica de um estado de espírito exaltado pelas melhores paixões românticas, a mensagem das cartas seria continuada nas colunas de "O Tífis Pernambucano", gazela que o mesmo frade faz imprimir em Pernambuco até meados do ano seguinte, 1824. Enquanto que as ponderadas cartas do Padre Sousa Caldas pertencem mais a um gênero amável do tratado social, os escritos de Frei Caneca encartam-se na vertente íngreme do ensaio polêmico, estuante de paixão partidária, ressaltando em pleno calor da refrega os dotes muito notáveis do escritor erudito, mestre de Retórica e Gramática, que bem sabe conciliar, na invenção agressiva, repente e artifício.

No panorama dessa vibrante literatura hebdomadária, aviada às pressas, quase sempre sem elevação, e que se prolonga até o fim da Regência, Frei Caneca ocupa lugar destacado pois modelou com talento superior língua e idéias do seu grupo, a elas comunicando voz muito própria. A sincera paixão patriótica, pela qual chegou até ao sacrifício da vida, fê-lo moldar a expressão das suas idéias num tom de grande funcionalidade, rico de humores eruditos e populares. E enriqueceu assim a nossa prosa de ensaio com os perigosos recursos da indignação, que ele laicizou no violento auto-da-fé radical que é a sua obra de escritor público.

\section{DO SERMÄO COMO ENSAIO}

Num ambiente em que até então a oratória sacra havia sido o épico da expressão literária da comunidade, situada bem no centro de uma vida social que girava em torno da igreja forum ć́vico e religioso, sala de estar de clero, nobreza e povo atingia esse oficio de pregar a mais vasta das audiências, 

(17):9-54, 1989.

acima de conventículos de sociedades secretas ou letradas. Seja pelo seu lado moralizador de sacra tribuna, seja pela obrigatória e brilhante versatilidade do contexto, o sermão culto, quase sempre cultista segundo a tradição mitificada de Vieira, incorpora-se e vai prevalecer como uma das linhas mais ortodoxas do ensaio. Isto, embora não possua da atitude mental do ensaio senão a aparência: a do comentário, como mote e glosa, no qual a entonação tem decisiva importância. E portanto bem expressivo que a transição do sermão barroco para o sermão romântico dê-se paralelamente à implantação do jornalismo panfletário, documentando nítida translação de preferências retóricas e utilização de tropos $^{(\mathrm{f})}$. Não se deve esquecer que muitos desses pregadores inflamados pela nova chama eram políticos ardorosos, que se revezavam entre imprensa, púlpito e parlamento - Januário da Cunha Barbosa, Frei Caneca, Frei Sampaio são expressivos exemplos desse livre trânsito, pregadores cujo prestígio ombreava com Frei São Carlos e Monte Alverne. O último, contaminado de modo decisivo por Chateaubriand, terá um lugar reservado nessa nova mitologia. Criara-se, em torno da sua figura de intelectual muito dotado, certa aura sugestiva que os discípulos imediatos dele, pontífices de nova escola literária, tentariam reproduzir não só na técnica da prosa envolvente (que incorporava neologismos polidos, próprios ou em favor da língua-modelo), quanto na sugestiva elegância romanesca de emporte $^{(g)}$.

A influência do sermão não pode ser esquecida, muito em especial no jornalismo de ensaio, quando judicioso e moralizador ${ }^{(\mathrm{h})}$. A repercussão dessa forma declamada na prosa literária corrente, a princípio graças ao automatismo e ao prestígio do costume arraigado, depois na forma do cultivo procurado e enfático do bem-dizer clássico, - explicará o tom guindado de muitos estilos do nosso ensaísmo até recentemente ${ }^{10}$ Tais galas retóricas servirão, em todo caso, para caracterizar o interesse pela expressão literária em si, no convulso mare magnum desse primeiro momento nacional. Se tal vinco beletrista degenerará mais tarde em literatice, em super ou em subliteratura, naquele período indica o respeito por um superior ofício de bem escrever, ou o

10 Seria interessante pesquisar, na inconsciente modulaçâo (k) ensaio brasileiro, lock) o peso que essa Iradiçîo afinal exterior, de receita, portanto, exerceu sobre nós, - aincla que menos intenso, talvez, daquele exerciclo subre a civilizaçáo colonial protestante. Al o sentido próprio de súbria meditaçăo sobre tema religioso ou ético já as tornava quase automaticamente e’sssưs no melhor sentido in literatura escrita, praticamente inclependente ch seu fim oral. Eo que acontece com a vasıa liternturn especializada que floresceu na Nova Inglaterra e que se prolongou coin alto nivel pelo Século XIX. Note-se alíís que o subttulo colocacto por Bacon na elição de 1597 dos Essays era exatamente Religious Meditations. Places of perswasion and disswasion, alterado na de 1625 para Cournsels, civill and morall. 
EUI ÁL.JO, Alexandre. O ensaio literário no Brasil, Língun e Llteralura, São Paulo, (17):9-54, 1989.

tácito acatamento do ideal da expressão letrada, que o plumitivo reconhece dever atingir pelo aprendizado.

\section{UMA OUTRA VARIANTE ENSAÍSTICA}

O revolto periodismo político do te mpo é um misto de panfleto, sátira, paródia, polêmica. Literatura de apóstrofe, fundamentalmente interjectiva, nela lanto vale a ofensa pessoal rasteira quanto o mais fino sarcasmo ou a declamaçãoapenasbombástica ${ }^{(i)}$. Pois é em meio assim revolto e conturbado que vai surgir de modo espontâneo o ensaio de teor subjetivo, crônica livre e fantasista que se desenvolve ao sabor da pena. Forma que apela para a ironia e para a imaginação em vez que para a ênfase, corresponde a um momento de pausa, de raciocínio, e exprime inequívoca consciência de superioridade intelectual. Até então desprezada, essa força revela-se das mais eficazes no aceso do desforço panfletário de após a Independéncia. É o período em que, empregada ainda de maneira impura, revela-se uma novidade de rara eficiência jornalística.

Vamos verificar isso, por exemplo, em alguns números de "O Tamoio" Folha da Corte administrada por Meneses Drummond, representa a posição dos Andradas na arena Jornalística do Primeiro Reinado. No $\mathrm{n}^{\mathbb{2} 22}$ dessa gazeta aparece a "Carta de João Claro ao seu compadre Brás Escuro", atribuída a José Bonifácio, curioso exemplo de ensaísmo involuntário; tudo indica que a necessidade de provocar a atenção do leitor faz o escriba apelar para o imaginativo, a fim de repisar de modo diverso a tecla de sempre. Editorial esta mpado em outubro de 1823, "onde se dão definições de opinião política, aura popular, déspota, patriotismo, ao sabor dos demagogos da época"ll, já está presente nele a estrutura do familiaressay, tal e qual entendida pelos folhetinistas ingleses do século anterior; inclusive através da presençá de ingredientes fundamentais quais a malícia e o humorismo.

O ne 5 do mesmo "Tamoio" já havia trazido pitoresca conversa familiar com velho filosofo, morador do Largo do Rocio, muito experiente da coisa pública e da política; no diálogo, referido com técnica quase romanesca, não se esqueceu o autor da entrevista imaginária de se referir até à "ironia

11 SOUSA, Oclavio Tarquinio de. "O Jornalismo da Independência", em Fatos é personagèns, cil., p. 30 . 

(17):9-54, 1989.

socrática" do anfitrião ${ }^{12}$ Descrevendo o interior espartano da casa, sem desprezar nem mesmo a figura do molecão que abriu a porta ao remoto repórter, essa pseudo-entrevista leva, nos seus primórdios brasileiros, outra vez o ensaio às origens que the propõe Mario Praz: diálogo a dois ou mais interlocutores (ou unilateral, nas cartas de ficção), e que o crítico italiano faz remontar à Atenas do autor do Banquete reinterpretada pelos saudáveis humanistas do Renascimento ${ }^{13}$

\section{DO COLOQUIAL}

Cartas fictícias já eram formalmente as de Sousa Caldas e Frei Caneca, na verdade "discursos morais", dissęrtaçōes eloqüentes ou agressivas, mas que não pretendiam dispor do ele mento de naturalidade, entendido como sal familiar. Agilidade e desenvoltura propícias senão à alta crítica moral, pelo menos ao juízo imediato dos costumes e idéias em voga, inerente ao surrado e sempre constante "castigar dos costumes pelo riso". Será um terceiro clérigo - ele também professor de Retórica, jornalista, político, pedagogo - a figura que melhor representará esse tipo do livre comentarista satírico da época, aquele que o iria difundir e ilustrar por largos anos afora: Lopes Gama, Frei Miguel do Sacramento Lopes Gama.

Homem da imprensa política que redigiu nada menos que cinco jornais militantes, de 1822 a 1846 , foi através de uma sexta folha, "O Carapuceiro", periódico sempre moral e só per accidens político, que ele por assim dizer estabelece e firma esse tipo de ensaio entre nós. Será o primeiro dos nossos cronistas, dando ao gênero um brilho e formando um público até então inexistentes.

12 Idem, idem, idem. Relacionando estes dois exemplos brasileiros com a Iraduçâo mais ilustre do genero, citamos outra vez o trabalho de J.M. Berdan: "Erasmus wrote an open letter when he wished to defend his translation of the New Testament, and Sir Thomas More used the same form when he wished to defend Erasmus. Similarly, when More derired to attack the reformers, be imagined himself interviewed; and when Erasmus wished to discuss the questions that were convulsing Europe, he wrote a series of dialogues" Cf. com o citaclo verbete th Colliers Encyclopedia.

13 Saqqio, verbete da Enciclopedia Italiana. "Il tono peculiare del saggio, di disinvollura e familiaritá col lettore gli viene infatti della forma epistolare che ne e alle origini, adottata da Cicerone, accanto al dialogo (di origine platonico) per piò commoda e divulgativa esposizione di soggeti filosofici. Il pretesto epistolare spesso non supravviveva che nella soprascrita, ma anche se appena accennato (...) faceva sentire il suo influsso nella spigliatezza del ragionamento che legava insieme quel florilegio di massime degli antichi, di esempi e di nncdotti, che costitutiva il nucleo dei tratatelli umanistici" 

(17):9-54, 1989.

A extraordinária vivacidade imaginaliva aliava-se nele a uma visāo crítica das coisas, sensível como era a loda espécie de ridículos e prelensões, que debicava com graça muito sua. Dolado de grande poder descrilivo, recolhe u como que sem se aperceber, precioso documentário geral de usos e costumes de todas as esferas do tempo. Testemunha participante de uma época em acelerada transição, uma época que com entusiasmo demasiado superficial acolhia toda espécie de novidades, Frei Miguel zurziu com gosto, num tom chocarreiro muito próprio dele, todos os sestros da moda e da gamenhice. Repousando o seu bom senso nativo em sólida visão do mundo, que a fé em Deus, nas Letras e na Moderação lhe havia comunicado, não fazia concessōes. Servido por um estilo elegante e fácil, de grande ductilidade expressiva, ocupará a posição de sardônico defensor da posição do analista sem ilusões, mas também sem intolerância, que só tem compromissos com o razoável. Enfim, uma espécie de recteur paternal cuja arma irresistível era a ironia.

\section{O LUGAR DE LOPES GAMA}

A fama de "O Carapuceiro" publicado no Recife, atingira em breve todo o Império. Em 1840 Lopes Gama assume uma cadeira de deputado geral, e por isso vê-se obrigado a interromper a publicação da folha, iniciada oito anos antes. Diante de insistentes pedidos, reloma-a no Rio de Janeiro: é o tempo de "O Carapuceiro na Corte", tão brilhante como o da época recifense, e alcançando um público ainda maior. Terminado o mandato, com ele volta outra vez para a província; então está no auge a sua popularidade de rabiscador público. José Feliciano de Castilho já anotara em 1845 n'"A Regeneração" de Lisboa: "Um dos escritores vivos, em língua portuguesa, mais original, mais gracioso e mais popular na terra de nossos irmãos é sem dúvida o redator do antigo jornal 'O Carapuceiro' O seu estilo fez muilas vezes le mbrar o do famoso Addison, e numerosos escritos do nosso colega nada têm que invejar aos ólimos do 'Spectador, 14" A referência ao "Spectador" e a Addison conscientizava um processo comum, colocando o frade na sua própria tradição, tanto mais que a gazeta de Lopes Gama podia subscrever literalmente as palavras de Steele, na edição em livro de "The Taller": "The general purpose of this paper is to expose the false arts of life, to pull off the disguises of cunning. vanity, and affectation, and to recommend a general simplicity in our dress, our discurse, and our

14 Apud Barbosa Iima Sobrinho: Nola a Os precursores do Conto mo Brosil. Rio de Janciro, (ivilizaçăo Brasileirn, 1960). (Panorama do ('onto Brasilciro 1) p. 222. 
hehaviour ${ }^{15}$ É o que diz Frei Miguel com chiste muito seu, na edição de 19 de abril de 1837: "Eis torna 'O Carapuceiro' não para bússola da senhora opinião pública, como soem apelidar-se quase todos os periódicos (...); a minha musa rasteira não é para vôos tão levantados: muito fará ela se rastejar pelos tril hados campos da moral, tomando a peito a sátira dos vícios ridículos; e se, alguma vez, tentada e avexada do espírito dominante, der alguma rajada de política, será per accidens, sempre a medo dos sabichões (que hoje pululam de todos os cantos, como beldroegas) c nunca será para se dar por infalível em suas opiniōes" $\mathbf{E}$ mais adiante: " 'O Carapuceiro' continuará, finalmente, como principiou, istoé, guardando se mpre a epígrafe que tomou, falando dos vícios e nunca das pessoas. Quem the servir a carapuça, fique-se com ela bem caladinho e corrija-se, que é o essencial"16

Nesse espaço literário que se constrói uma língua própria, flexível, transição entre o livresco e o popular, Lopes Gama tem papel ainda mais importante por ser polígra fo altamente erudito. Responsável ele também - como Frei Caneca e Sousa Caldas - por lições de Eloqüência Nacional, nelas repontam os seus marcados dotes de crítico e a visão desempenada do homem cul to, no alto sentido desta palavra. Transformando a paixão política em lite ratura de combate num plano artístico superior, desinteressado, ele realizava verdadeira obra de civilizaçāo, ainda mais quando se leva em conta o teor imediatista das letras ainda na primeira metade do Século XIX.

\section{O APARECIMENTO DO FOLHETIM}

A essa altura a década de 30 o ensaio, nas suas tendências extremas de quase ficçāo ou de qualse política. começava a generalizar-se pela prática do folhetimi. Se a nova espécie jornalística ganha tal nome somente na

15 Apud Jane H. Jack: "The periolical cssaysts" em From Diyden to Jolmson, edited by Boris Ford. Londres, Peinguin, 1960 (The Pelican Guicte lo English ! iteralure 4) pp. 219-220.

16 Em Lopes Gremu, textos escollhidos por Luís Delgado. Rio de Ianerro, Agir, 1958 (Nossos Clássicis 31), pp. 23, 24 e 28. "Nenhuma crônica chos nossus costumes - escreve Luls Delgacho na aprescntaçĩo ha sun antologia - é mais digna de leilura, do que a coleçâo dessa folha de Frei Miguel. Retrata sinuultaneamente os nossos modos de ser cotidianos e a ironia do inteligente ubservachor. Não era apenas a respeito de molas e de comportamentos domésticos que 0 jornalista escrevia: escrevia também sobre as iuléias que circulavam, sobre as leis e us códigos que se clecretavam. A inveuçâo mental e a graça de expressão deixavam transparecer algo mais profundo, a intençito do moralista. Interrompich algumas vezes, publicalo aqui ou ali, "O Carapucciro" Jurou quatorze anos. Tudo faz crer que lenha tido um êxito rarissimo." Lopes Gama, p. 10. 
edição de 4 de janeiro de 1839, no "Jornal do Commercio" da Corte, vinha aparecendo debaixo dos títulos de variedade, literária, apêndice, desde dois anos antes, e já se havia generalizado como seção fixa das fol has de primeira ordem. $O$ desenvolvimento constante da imprensa, organizada em torno da politica, não exige mais apenas que esta ocupe o noticiário. A literatura amena, conformada por ela a princípio, mas logo depois independente, terá caráter alusivo nas suas origens, disfarçando de maneira mais ou menos alegórica os acontecimentos políticos. Literatura que por isso não precisa ser $a$ clef, mas não abdica dos gêneros alusivos.

"Filho mimoso e brilhante da imaginação, que trajas ricas galas que te cobres de jóias preciosas" - conforme o invocava Justiniano da Rocha ${ }^{\text {P7 }}$ o folhetim, na sua qualidade de comentário sem maiores compromissos de acontecimentos e episódios, empolgaria o sentido da crônica de variedades - ora a nota de costumes e a descrição de tipos, ora a fantasia apologal ou a polêmica moralizadora.

\section{GRANDEZA E POBREZA}

"Tratava-se, em última análise, de um noticiário submetido a um tratamento literário. $O$ cronista percorria os assuntos, discutindo-os como homem de espírito", resume Brito Broca ${ }^{18}$ "Os moldes então adotados consistiam no encadeamento mais ou menos arbitrário de vários temas por meio de uma deixa estratégica". Os folhetinistas "entremeavam os flagrantes de costume com os comentários políticos, a crítica da última peça representada, ou as mais recentes notícias do Estrangeiro 19 "

O gênero é ingrato: exige muito e o resultado é pouco mais do que nada. "Beneditinos da história mínima e cavouqueiros da expressão oportuna" conforme dirá Machado de Assis, em 1878, "vivemos seis dias a espreitar os sucessos da rua, a ouvir e palpar o sentimento da cidade, para os denunciar, aplaudir e patear, conforme o nosso humor ou a nossa opinião, e quando nos sentamos a escrever estas folhas volantes, não o fazemos sem a certeza (ou a esperança!) de que há muitos olhos em cima de nós. Cumpre ter

17 Apud Barbosa Lima Sisbrinho, ob. cit., Introduçăo, p. 16. O texlo e de "O Chronista" (1836), periódico dirigido por Justiaiano da Rocha. Seguimos aqui, em traços gerais, o referido ensaio de Barbosa Lima Subrinho.

18 "Cronistas de Outrorn", recorte da "A Gazeta" de Sfó Paulo, sem dala (1947).

19 "Os marionetes de uma civilizaçho" em Horas de Leitura, p. 121. Rio de Janeiro. Instituto Nacional do Livro, 1957. (Biblioteca de Divulgaçăo Cullural X). 

(17):9-54, 1989

idéias, em primeiro lugar; em segundo lugar expô-las com acerto; vesti-las, ordená-las, apresentá-las à expectação pública. A observação há de ser exata, a facécia pertinente e leve; uns tons mais carrancudos, de longe em longe; uma mistura de Geronte e Scapin, um guisado de moral doméstica e solturas da Rua do Ouvidor..."20

A improvisação tem lugar importante nesses rodapés que fazem a delícia do leitor. Com a bonomia de sempre França Júnior, outro cronista impertérrito, escrevia em janeiro de 68 no "Correio Mercantil": "O folhelim é um verdadeiro salão de baile: entra-se nele sem se saber o que se vai dizer" ${ }^{21}$ para em outra parte caricaturar-se num tom divertido: "O escritor de rodapé é o ente mais desgraçado que pisa o solo das capitais; não the é dado sequer ter uma dor de cabeça: um teatro, um baile, o acontecimento mais pequeno da semana, reclamam a sua presença, e ou por fas ou por nefas tem de aparecer em seu posto de honra no dia em que the cabe a palavra. É um dono de casa, que anunciando aos amigos que recebe em dias cerlos, tem a rigorosa obrigação de apresentar-se aos habitués dos seus sálóes, sempre de ponto em branco, de disıribuir cortesias à direita e à esquerda, como o nosso amigo dos colarinhos, e mais que tudo isso, de pôr um riso efetivo de amabilidade nos lábios, até que saia o último convidado" 22

\section{PRIMEIROS CULTORES}

Coincide assim com o encerrar-se do Primeiro Reinado e princípio do período regencial o aparecimento dos primeiros grandes folhetinistas. O amadurecimento da imprensa, com a progressiva divisão das tarefas e seções do jornal moderno (das quais a menor inovação não terá sido a. notícia, ele mento quase ine xistente na gazela primitiva) cria a necessidade desse ensaísmo ligeiro e bem humorado, no qual vão adestrar-se, por premência ou desfastio, alguns dos primeiros nomes do período. Justiniano José da Rocha. Firmino Rodrigues Silva, o espirituoso Josino do Nascimento Silva, Francisco de Paula Brito, Sales Torres Homem - viriam a ser as maiores e mais representativas figuras do periodismo do tempo, todos eles tendo incursionado pela política, através do jornalismo partidário è da administração pública.

20) Notas Scrmanais, 4 de agosto de 1878. Otrá Ciompleta, Vol. III, p. 428. Rio de Janciro, Aguilar, 1959.

21 Polltica e Castumes, p. 154. Rio de Janeiro, ('ivilizaç̧ó Brasileira, 1958.

22 Idem, p. 135. () lexto é de 24 de novembro de $180,7$. 

(17):9-54, 1989.

Irresistível pela fascinação que exerce sobre a fantasia dos leitores, o folhetim havia-se constituído numa prática agradável a que de modo algum se furtam os intelectuais de então. Anônima ou assinada apenas pelas iniciais, essa literatura leviana, de autoria facilmente atribuível na grande aldeia que é a Corte, é a prova que todos os "belos talentos" têm de passar, antes de receberem de vez seus preciosos diplomas de almas sensíveis e espirituosas.

\section{A CORTE CIVILIZA-SE}

Esse evoluir da correspondência de teor erudito para o cartear íntimo, em tom faceto e desenfadado, próprio do folhetim romântico, assinala decisiva estratificação de interesses no interior do jornal novecentista. Denunciando relações e necessidades diferentes, dentro de um todo social até então indiferenciado, a folha abre espaço para certo público que até então não contara de modo nenhum para os seus organizadores. Trata-se da "gentil leitora", silhueta amável cuja presença só fora notada em algum raríssimo periódico ameno, mas agora exige redator especializado e rodapé apenas seu, até mesmo nos grandes diários. "... e porque o folhetim requer um ar brincão e galhofeiro, ainda tratando de coisas sérias...." ${ }^{23}$, os dengosos bilhetes aos amáveis olhos que nos lêem tornam-se característicos da onda de mundanismo que invade o Rio de Janeiro neste primeiro seu civilizar-se.

A inseparável repercussão estilística desse fenômeno evidencia-se imediatamente nos maneirismos mais ou menos comuns a esses escrevinhadores de letras caprichosas. Francês a tiracolo e inglês na algibeira, os cronistas fashionable da boa sociedade fluminense registram e comentam todos os acontecimentos da atualidade mundana, numa prosa que procura abrir o seu caminho dentro dos meandros fantasistas daqueles que a escrevem. Se o estilo deve ser correntio e sem maiores arrevesamentos, que acolha também as inovaçōes do momento em favor nas rodas mais categorizadas.

\section{CONQUISTAS}

É inegável o serviço de desbravamento e de construção realizado por esses pioneiros, que abordam, pela primeira vez, o coloquial. Através de contacto direto c constante com o público letrado, do qual ao mesmo 

(17):9-54, 1989

tempo acompanham e dirigem o gosto, essa prosa será o veículo mais dire to para decisiva oralização da língua literária, que se realiza através do imediato aproveitamento culto do bem-falar das sucessivas épocas com que os "cronistas" dialogam. Tratamento aliás bastante livre do coloquial erudito do dia, aberto como sempre o foi, em especial na área fluminense (carioca), às invenções da gíria e do jargão do momento, aí sempre tão espirituosos. Assim o familiaressay brasileiro contará com diversas oportunidades plásticas para enriquecer a sua prosa, num intercámbio dos mais sugestivos com a língua falada. Por este caminho variados elementos renovadores - léxicos, sintálicos - alcançaram ainda muito cedo até a prosa de fiç̧ão, que com eles se enriqueceu notadamente no campo da afetividade ${ }^{24}$

\section{LEVANTAMENTO DE TIPOS E SITUAÇÕS}

Termômetro dos interesses do meio, ao mesmo tempo que esboço da comédia dos costumes representada na Corte e na Província, o folhetim de variedades realizará uma autentica catalogação de tipos e situaçōes da vida cotidiana. Panorama limitado pela autocomiseração irônica, é bem verdade, mas alguma vez caminhando para uma análise severa da sociedade circunstante, - como é aquela que pratica, com critério evolucionista de egresso da Escola do Recife, um Celso de Magalhães no rodapé de "O País", do Maranhão, em idos de 1870. Dessa forma o levantamento crítico das ocorrências costumeiras e dos espécimes característicos das áreas e sub-áreas burguesas reveza-se com o registro copioso dos ecos teatrais. na forma seja de crônica seja de crítica dos espetáculos: óperas, concertos, dramas, comédias. É bem conforme com o espírito do tempo que o teat ro suceda à igreja como o centro da vida social da comunidade; os folhetinistas não podem deixar de acompanhar a tradição. Dividem com o público o apaixonado partidarismo favorável ou contrário não mais a este ou aquele pregador, mas a uma ou outra atriz.

$\mathrm{Na}$ Corte, nas capitais das províncias, em especial naquelas de importante vida académica ou cultural (Recife, Salvador, São Lứs, São Paulo) um teofrastismo diluído levantamento da galeria de exemplares do círculo social - acaba por procurar menos caracteres do que chaves, quase sempre tomando coloração demasiado pessoal e degenerando para a polêmica. Consegue

24 Alencar, folhetinista que publicou us seus romances ein rodapés fez uso nas novelas urbanas de alguns plebelsmos em voga, abonando-se do uso corrente deles pela melhor gente da Corte. Talvez por isso the parecessem definitivamente cunhacks, com livre iransito na IIngua literaria. 

(17):9-54, 1989.

deste último modo agitar o meio, posto em xeque pela exibição dos seus tiques e cacoetes, ainda que tal agilação nem por isso perca a própria insignificância provinciana. Meramente salírica, a crílica que exercem é contudo uma cunha do espírito revisionista, que agirá no sentido de alimentar o inconformismo das novas gerações.

\section{FOTOGRAFIA E MEIO}

Exigindo vivacidade e graça, precisão e fantasia, o folhetim é criação do Romantismo que o Realismo-romântico e Realismo-naturalista hão de desenvolver em todas as suas possibilidades até como que as dissolver no pontilhismo de sensações vagas e experimentação expressiva fronteiriça ou anexa à prosa poética simbolista.

Dentro de uma tal linguagem, que depois conlinuará o seu evolver costumista até aos nossos dias, Machado de Assis levará ao mais alto rendimento artístico o esforço coordenado por três e quatro gerações, a partir de Lopes Gama e do grupo de Justiniano da Rocha, que são contemporâneos. Sem cronologia rigorosa, até o fim do século e princípios do seguinte a eles se reúnem: Martins Pena, Henrique César Muzzio, Joaquim Manoel de Macedo, Augusto Emílio Zaluar, Ferreira de Meneses, Francisco Otaviano, José de Alencar, Quintino Bocaiúva, Manuel Anıonio de Almeida, Ferreira de Araújo, França Júnior, Urbano Duarte, Machado de Assis, Joaquim Serra, José do Patrocínio, Artur Azevedo, Lúcio de Mendonça, Paula Ney, Raul Pompéia, Pardal Mallet..., para cilar apenas os mais conhecidos ou notados.

\section{PAISAGENS E INTERIORES}

Não é necessário encarecermos essa borboleteante representação exterior de um meio $\mathrm{cm}$ mudança. Retratava objetivamente uma realidade cujo sistema de aparências, aceito sem maiores problemas, era agora posto em discussão. Tanto assim que a mais importante obra de sondagem social e psicológica da nossa literatura - decisiva pela precisão analílica, pela finura sem concessões, autêntico corle na máquina do pequeno mundo brasileiro foi realizada exatamente pelo mais bem dotado dos folhe tinistas "amenos", Machado de Assis. A obra de ficção dele é o meticuloso mapa sísmico daquela mesma sociedade que, como cronista, fixara nos seus estremecimentos mais ligeiros e mais aparentes ao mesmo tempo. 

$(17): 9-54,1989$.

\section{A BASE}

Bem conforme o espírito contraditório da incipiente "civilização brasileira", o ideário dessa atualização de valores (porque quase disso se enfeila a crônica de costumes de então) no fundo é ainda joanino, codificado pelas modestas máximas de Maricá, divulgadas em primeira mão no distante "Patriota". Caracterizava-se esse ideário - segundo a observação ácida de Mota e Silva - por um bom-mocismo de senso comum, estoicidade distraída ao sabor dos costumes, muito mais entranhada na mentalidade geral do que poderia parecer a um primeiro exame, porque acessivel a todos e até aberto a um moderado humanitarismo iluminista ${ }^{(0)}$. A um tal estado de ânimo, ausente de qualquer possibilidade mais densa de conflito, sucederá em determinados grupos seja a ética positivista, seja o ardor filosófico pelos novos credos spencerianos, seja a recolocação da fé católica em bases de combate vivo, depois da dura prova que foi a "Questão dos Bispos"

Era inevitável o choque entre a mentalidade tradicional e o posterior empenhar-se em atitudes coerentemente doutrinárias, como as indicadas. Ainda que elas implicassem num revisionismo decerto superficial, aceito de forma global $^{(1)}$ e sem possibilidades de análise crítica pelos catecúmenos, revelam característica mudança do meio brasileiro cultivado, datando com um antes e um depois a "inquietação moderna" Essa variaçāo de diretiva doutrinária no interior de espíritos da mesma forma românticos, como que vai separar o país em duas épocas de distinta mentalidade.

\section{A EXPRESSĀO LITERÁRIA E OUTRAS PESQUISAS ENSAÍSTICAS}

Então o fato social concreto, encravado na realidide do país, também encontra os seus críticos independentes. À margem da agitação partidária, que se reveza no Poder, exercendo-o com os mesmos expedientes que verberam quando na Oposição, existem alguns estudiosos que investem contra esses moinhos monstruosos se não com imaginação pelo menos com ímpeto romântico. É o caso do moralisno verdadeiramente ético de Joāo Francisco Lisboa, revoltado com o formalismo de fachada, que escamoteia a realidade dos fatos políticos e sociais, em benefício de mandôes sem sombra de espírito público. Do modo mais cru realiza ele no Jornal de Timon a radiografia do coronelismo paternalista; o seu protesto é o mais veemente e o mais irrespondível dos que se tem notícia nesse período, escrito numa língua tersa e dircta, de excelente corte vernáculo, qualidade que se alirma nos demais escritos históricos do autor. Obra que transcende a Literatura pelas suas intenções, pode ser 

(17):9-54, 1989.

colocada dentro do ensaísmo não-literário brasileiro ao lado das de Tavares Bastos (A Província; Cartas do Solitário), do Visconde de Uruguai (o Direito Administrativo), de Couto de Magalhães ( $O$ Selvagem), como algumas das melhores e mais percucientes aproximaçōes da nossa realidade no Século XIX. Nesta tradição de estudos políticos concebidos numa linguagem incitante, encartar-se-ão mais tarde os trabalhos de um Assis Brasil (Democracia Representativa), um Alberto Torres (O Problema Nacional do Brasil), de um Oliveira Viana ( $O$ idealismo da Constituição), autores em que o tema encontra um estilo para se exprimir.

Dentro da ética também ela romântica, tentava-se então, do mesmo modo, nesse período de individualismo mais ou menos absoluto, o mergulho no interior do eu debaixo de forma que se pretendia filosófica, e $e$ natural encontrasse no ensaio um dos mais apropriados derivativos de expansão. Sofrendo no seu primeiro período o influxo de diversos elementos, e não dos menores por parte do púlpito romântico, esse tipo de prosa expositiva dará acolhida a diferentes espécies de divagaçōes, meditaçōes, evocaçōes, numa constante que não se esgolará de Gonçalves de Magalhães a Graça Aranha. Ensaistas que perseguem a realidade úllima, numa prosa que por se pretender sistemática não dispensará as galas de estilo, Magalhães, Pedro Américo (filosofante além de pintor), Tobias Barreto, Farias Brito, Graça Aranha ${ }^{25}$ tentarão posições conciliatórias dos diversos estágios do pensamento novecentista, a partir do ecletismo mais ou menos cousiniano, que influiu Montalverne e marcou os epígonos, até o neo-panteísmo evolucionista de Aranha, ersatz tardio e eloqüente do spenceriano tobiático.

\section{SÁTIRAS}

A Meditação, de Gonçalves Dias, fragmentos de Romantismo messianico, com seu tom de apocalipse menor ${ }^{26}$, se à primeira vista parece

25 "De comum com Tobias, tem Farias Brito a desigunldude na forma de expressar seu pensamento. Em Tobias, a seriedacle intcloctual nåo the impedia de ceder à lenlaçño de expressóes chulas ou de invectivas passionais. Em Farias, homem mais grave $\epsilon$ bem composto, nâo surgem tais liberclacles no tralu de pessons ou de idléias, mas aparecem, cumn alguma frequência, as tiradas retóricas e as arremedos lfricus que clesqualificam muitas de suas púginas, sem lhes acrescentar valor estelico. Num, a pilheria de sabor provinciano c popular, ou a invectiva passional e injusta (...) nlem clo mau gosto retúrico (...); no outro, a literntice piegas ou a retórica inflada. Em ambos, no entanto, uma grande paixf̃o intelectual" Hélio Jagunabe: $A$ Filosofia no Brasil, pp. 37, 39 - 41. Rio de Janeiro, ISEB, 1957. (Texlos Brazileiros de Filusofia 2).

26 C. Antonio Canclido, ob. cit., vol. Il p. 52-53. 
aproximar-se do grupo acima, aparenta-se ao contrário através de Alexandre Herculano com a literatura de reivindicação, paralela, afinal, ao nada alegórico Jornal de Timon e às sátiras políticas de implícito ou explícito caráter utópico. Destas sáo exemplo, tanto pela ironia e pela violenta repulsa que retratam, como pelo transparente disfarce de ficção com que se revestem, o Código C'runinal da Semi-Repüblica de Passamão na Oceania (1841), de Lopes Gama; as Páginas da Historia do Brasil escrita no ano de 2000 (1868-72), de Joaquim Felício dos Santos; ou as Notas sobre a República das Bruzundangas (1917), de Lima Barreto. A agressão contundente aparenta esse gênero híbrido por um lado com a literatura panfletária, por outro com a crônica fantasista e o apólogo moralizante. A intençăo ensaística continua presente na sátira através do espírito de análise e comentário, próprio a ela. Arremedo grotesco de uma situação real, transposta para termos caricaturais, constitui evidente reflexão alegórica sobre determinada circunstancia.

Mais próximo do tom carapuceiro estão as caricaturas literárias da vida do país gizadas por Macedo em A C'arteira do meu Tio, e, continuação desta, nas Memórias do Sobrinho do meu Tio, livros que de modo mais brando exploram a mesma vertente tipicamente intelectual do ensaio: a paródia literária $e$ a literatura de chave. Alencar também deixou no gênero um fragmento: A Corte do Leão, obra escrita por um Asno, talvez o seu melhor escrito satírico; uma página rara, que tendo perdido a significação propriamente alusiva, continua a valer no campo muito mais vasto da fabulação de exemplo.

\section{PANFLETOS}

À sátira mais propriamente política liga-se a literatura de panfleto, a polêmica, e a sua versão torpe, o pasquim, variantes quase sempre corrompidas do ensaio. Variante que aproveita, numa escala amplificada, da deformaçăo de elementos caricatos e burlescos, servidos de modo especial, na esfera ibero-americana que é a nossa, pela ênfase, essa primeira transformadora da reaiidade. A maioria dos nossos panfletos políticos, do Romantismo ao Realismo naturalista Libelo do Povo, Conferéncia dos Divinos é servida de eficaz expressão literária, muito realizada no sentido dinamico de levantar indignação. Seguiain elas também o esquema retórico do deleitar, convencer $e$ persusdir dos manuais de Eloqüencia, a fim de "influir sobre o regime dos negócios $^{27}$ Cabe à análise estilística dizer a última palavra a respeito do seu

27 CARVAl.HO, Francisco Freire de Liģöes Elementures de Elogüência Nacional, 6' ediçhó, p. 18. Lisbora, Typographia Rullandiana, 1861 

(17):9-54, 1989.

débil conteúdo não-imprecatório, e à Sociologia da História a sua adequação crítica à realidade brasileira do momento.

\section{A CRÍTICA}

Já então a espinha dorsal de toda essa literatura, que conquista sempre maior consciência de missão, é sem dúvida a Crítica. Musa retardatária, matriculada por último num jardim do Parnaso cheio de mato, já então estávamos longe da sua concepção como aquele conhecido processo de sanções e louvores proferidos debaixo de qualquer zimbório académico as mais das vezes apenas imaginário.

A experiencia do Romantismo fora fecunda. A própria fundação do movimento havia-se apresentado antes de tudo porque decisão consciente e raciocinada de caráter ensaístico. O sentido cosmopolitizante que ele tomara. espécie de acertar os ponteiros culturais com o mundo pensante, segundo determinado plano de reformar o país conforme o ponto de vista das letras, passou-se antes no campo da exposição e da divulgação das idéias, do que no campo criativo. Segundo sempre acontece, a exemplificação prática, sua coetânea, é transparentemente inferior à teoria, e quando muito ilusira de modo passável as teses defendidas. É que se o esforço vigilante de cumprir um programa se ajustava ao que necessitávamos, coibia também a criação mais livre, como que propondo certa fórmula de execução demasiado penosa.

\section{IMPRENSA, ENSAIO, CRÍTICA}

Conforme já vimos, o desenvolvimento da imprensa toma a partir da década de 1830 marcado sabor literário. As belas-letras haviam passado a integrar definitivamente o periodismo. Anteriormente afagadas por um ou outro amador, como Evaristo da Veiga, que não deixava de animar talentos nascentes através de elogiosos editoriais, agora são parte inseparável dos periódicos, ocupando talvez a melhor parte deles. Conforme o acaso de ser a administraçáo mais ou menos interessada pelas artes, ou a coincidência de maior ou menor grupo de plumitivos na redação, o ensaio tem, ao lado dos outros gêneros, as mais diferentes oportunidades de se experimentar: crônica das novidades do dia, crítica de livros, de idéias, política, música, artes plásticas, teatro - tudo encontra lugar na folha. Mais do que simples diários, o "Jornal do Commercio", a 

(17):9-54, 1989.

"Marmota Fluminense" "Actualidades" "Correio Mercantil", "Diário do Rio de Janeiro", "Gazeta de Nolícias", "Cidade do Rio". - para ficarmos na Corte e no Oitocentos são verdadeiras coletâneas da atividade cultural do tempo, que não se podia espraiar em mais nenhuma parte.

\section{NOS ARRAIAIS DA IMPRENSA}

Os tentames dos propagandistas teóricos da nova escola romântica, fortemente coadjuvados pelo espírito da imprensa européia, como que modelam a nossa. Folhetinistas e editores das escassas revistas populares da época - Monitores, Minervas, Panoranas, Curiosidades, Universais -, ou pertencem ao grupo renovador, ou the seguem as pegadas. $O$ caminho foi aberto pelos artigos e prefácios expositivos do grupo da "Nyteroy". e a primeira geração de discípulos mais ou menos ortodoxos acompanha a obra dos mestres no campo novo do ensaio crítico. Abreu e Lima, Emílio Adet, Santiago Nunes Ribeiro, Joaquim Norberto, Paula Meneses, Dutra e Melo, tanto esboçam a teoria da crítica romântica aplicada ao caso brasileiro, como ajustam-na à produção, que começa a tomar existência nas próprias revistas e jornais em que eles colaboram.

\section{PRIMEIROS TEMPOS}

Sílvio Romero limitou esse período decisivo entre os vinte anos que vão de 1831 a $1851^{28}$ mas podemos estendê-lo por mais dez anos, até $61^{(\mathrm{m})}$. Mais importante ainda que o esforço compendiador de um Fernandes Pinheiro e um Sotero dos Reis (que vêem a literatura como ciência especifíca, mas do ponto de vista da Retórica e da Eloqüência), mais importante que o esforço desses professores é aquilo que Antonio Candido chama de "crítica viva" isto é, a participação no debate estético dos criadores, que disculem idéias e prálica da composição. Neste sentido é allamente expressiva a atitude de análise de Junqueira Freire, Álvares de Azevedo. Francisco Otaviano, José de Alencar, Gonçalves Dias, Machado de Assis, Bernardo Guimarães. Trabalham a prosa de ensaio como até então ela não o havia sido, propondo-lhe maior rendimento plástico e expressivo.

28 Datas respectivamente du Parnaso Brasilciro, de Januário Barbosa, e do Florilégio, de Varnlagen, Cf. com Quadro sinuśrico de evoluşäo des gêneros. Rio de Janeiro, Garnier, 1909. 


\section{POLEMICAS}

Outro modo pelo qual a crítica vai se manifestar e com a maior vivacidade, será através de polêmicas literárias. Verdadeiras batalhas campais, dão inusitada vivacidade a um ambiente sempre tão insensível à coisa literária propriamente dita. Seja em torno de um poema como A Confederação dos Tamoios ou uma antologia crítica como o CancioneiroAlegre, de personalidades culturais como Tobias Barreto ou Machado de.Assis, obras como O Primo Basílio ou A Carne, a polêmica empolga o meio cultural provinciano. Nos mais diversos grupos acompanham-se com atenção as lutas de Alencar contra Nabuco, José de Castilho e Franklin Távora, como as arremetidas sempre contundentes de Laet, ou a "batalha" que, como a de Itararé, não houve do Realismo e do Parnaso. Elegância do estilo, correção da frase, propriedade dos termos; psicologia e erudição; estudos de patologia ou de belas-artes, pontos de vista opostos em filosofia ou culinária, dão margema esses encontros sempre violentos de personalidades opostas.

O sensacionalismo que envolve o gênero, o interesse de escândalo que despertam no geral do público, tem a vantagem de colocar os assuntos artísticos na ordem do dia, dando-lhes um interesse que de outra maneira jamais conseguiriam. Espécie dialética do ensaio crílico, diálogo veemente que se encaminha para a sátira, a polêmica colabora de modo tortuoso para a explicitação dos problemas estéticos.

\section{DAS REVISTAS}

Alé o aparecimento de Sílvio Romero, na esteira evolucionista desse desbravador de caminhos que é Tobias Barreto - renovador da linguagem do gênero pela introdução de tecnicismos até então como que ignorados no ensaio literário brasileiro -, é preciso encarecer também a atividade das revistas literárias especializadas.

Todo o nosso crnsaísmo teria ficado totalmente dependente do jornalismo, e limitado de modo decisivo pelas contingências da imprensa diária, não fosse o papel que elas exerceriam. Al o ensaio de idéias crítico, interpretativo, histórico - consegue espaço e clima propícios para se expandir conforme as suas próprias neccssidades.

De publicação dispendiosa, lutando com as maiores dificuldades para sobreviver, raramente alcançam o quarto ou quinto número se não dispõem de subvenção oficial. Acompanhando ainda o modelo enciclopédico 
(17):9-54, 1989.

de um "Patriota", esses jornais de ciências, letras e artes acolhem até o fim do século XIX tanto a monografia especializada como a notícia sobre os últimos acontecimentos $^{29}$, ao lado de versos elegíacos certa memória sobre o algodáo maranhense; da descrição do curso do Rio Araçuá, a resenha sobre o último romance de Macedo.

Não poderia ser diferente, naquele meio onde todas as dificuldades cerceavam o trabalho intelectual. País de senhores e escravos, sem tradiçáo de cultura, contando com público dos mais diminutos, dentro da escassíssima minoria alfabetizada, os periódicos que nāo tenham espírito compilador de almanaques ou jornais do lar, sucedem-se uns aos outros, e só não desaparecem de todo devido ao ent usiasmo quase adolescente dos colaboradores. Se excetuarmos a "Revista Trimensal" do Instituto Histórico e Geográfico, diretamente bafejada pelo monarca, que é dado às letras - o Auspice Petro Secundo está bem nítido na capa -, as demais sāo de regular efemeridade. "Minerva Braziliense" ", "Iris", "O Beija-Flor", "Guanabara", "Revista Popular", "Bibliotheca Brazileira", "Novo Mundo", "A Semana", "Revista Brazileira" (nos tres períodos) - representam incalculável esforço tanto intelectual quanto físico. Em compensação, sem elas não é possível, literalmente, escrever de modo satisfatório a história breve da cultura brasileira.

\section{NAS FACULDADES}

Depuração e concentração do esforço intelectual em sua área própria, independente da imprensa diária, os grêmios literários terão o seu esforço naturalmente prolongado pelas revistas das sociedades académicas. Pertencentes à esfera de extensão cultural do que era então ensino superior, divulgando trabalhos literários ou jurídicos, esses gremios incrementam a sequência ininterrupta da prosa ensaística. Espécie sempre incipiente de tradição universitária, ela parece contudo ter inflúdo de modo quase decisivo para a formação da "Escola do Recife" e a sua tralha cientificizante. Tanto mais que nestes estudos alguns elementos já se destacavam que, nos meados da década de

29 Na apresentarjlo da terceira época da "Revista Brasileira" (1895-18\%9) escrevia José Verissimo: "A nova revis:a tratará todos os assuntos e questóes que possam iazie:asssi à maluria do públioo (...) As giessises ooresítucionais, jurfdicas, economicas, potrticas e suciais em suma, que nos ocipem e preocupam a todos, ferto um lugar nas suas pagiras (...) Pretende (a "Revista Brasileira") simplesmente ser umn tribuna onde todus os que "innigm alguma colsa que dizer, e

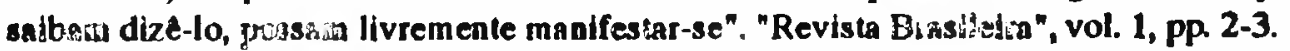


EULALIO, Alexandre. O ensaio literário no Brasil, I.Ingun e Lileralura, Şio Paulo, (17):9-54, 1989.

40 começam a se firmar definitivamente "no sentido de mais adiantadas doutrinas", conforme anotou Sílvio ${ }^{30}$ Nomeia ele nesse "começo de reação" contra o subjetivismo reinante, a Antonio Joaquim de Macedo Soares e Eunápio Deiró, alunos respectivamente de São Paulo e Recife.

\section{OS TOBIANOS}

O espírito englobante do culturalismo de Tobias Barreto, que estende a todos os domínios do espírito a perquirição erudita, "não em tratados longos e massudos, sim em rápidos e decisivos ensaios" (seguimos sempre Romero) ${ }^{31}$ marcaria de modo definitivo aquele que foi o seu grande devoto. Nesta linha totalizante hão de segui-lo os demais discípulos: Rocha Lima, Celso de Magalhães, Artur Orlando, Clóvis Beviláqua (que enveredaria pelo Direito), Martins Júnior, Graça Aranha, Adolfo Caminha, Tilo Lívio de Castro, Augusto Franco.

O primeiro deles, isto é, Sílvio, há de ser o grande coordenador da nossa cultura. Sem medo da tarefa tremenda, tenta o ambicioso levantamento e a organização sistemática de todas as manifestaçōes do espírito nacional. A Introdução d Historia da Literatura Brasileira, de 1882, e a propria História, conclurda seis anos mais tarde compostos ao mesmo tempo em que publicava inúmeros outros trabalhos de follego, literários ou não -, reservar-lhe-iam desde logo um lugar central em nosso ensaísmo, que ele se apressou a ocupar com todo o gosto.

\section{INDEPENDENTES}

Não quer isto dizer contudo fosse ele o único ou o mais representativo crítico da geração. As décadas de 70 e 80 assistiram também à estréia de figuras do porte de Joaquim Nabuco, Rui Barbosa, Capistrano de Abreu, Araripe Júnior, Carlos de Laet, José Veríssimo, Eduardo Prado, Joáo Ribeiro, sem esquecer figuras secundárias no gênero de Valentim de Magalhảes ou Melo Morais Filho, e vocações precocemente desaparecidas, como Rocha Lima, José António de Freitas ou Celso de Magalháes. Autores de diferentes linhagens criticas - para louvar-nos da frase de Wilson Martins, ${ }^{32}$, ensalstas de

30 Quadro sintético, cit.

31 Idem, Idein.

32 A Crrtica listerdria no Brasil, p. 22. Sño Paulo, Departamento de Cultura, 1952. 
expressão e qualidade muito diversas, estreando na Corte ou na Província, sofrem todos eles o influxo das idéias que estão no ar.

\section{NACIONALISMO: REVISIONISMO}

O Romantismo, que para a vanguarda agora já contava como peça do passado, tivera a prerrogativa de colocar em primeira plana, e de diferentes modos, o problema do nacionalismo literário. A dicotomia nacionalismo-cosmopolitismo, que tomara certa primeira configuração ao tempo do Realismo-romântico, com algumas doutrinas vagamente revisionistas dos costumes e da sociedade, faz com que o pensamento crítico volte-se a pouco e pouco para a realidade nacional, mas de modo radicalmente diferente do que o faziam Norberto e os companheiros de geração ${ }^{33}$

Esse interesse pela realidade brasileira apura-se com os ideais de precisão "científica" do Realismo-naturalista, contemporânea à renovação de ideais proposta por Tobias no Recife. Pelas suas possibilidades de um sadio universalismo, que decerto conseguirá despertar a mentalidade embotada do País, explica-se ao mesmo tempo o espírito revisionista de uma publicação como a "Revista Brasileira" (da segunda e terceira épocas), nosso primeiro mensário de sentido moderno. Tentativa de uma análise outra da cultura nacional, objetiva, direta, onde vão se ensaiar, com critério científico (o adjetivo é indispensável então) distintas pesquisas sobre as nossas coisas, ela pretende ser e será - o órgão deste espírito renovador.

\section{VERÍSSIMO E SEUS AMIGOS}

Ensaísmo que se quer sem ingenuidade, explica, por exemplo, a evolução de um José Veríssimo a partir de esludos cullurais lato sensu, para a pesquisa literária específica da madurez, em seus últimos anos. Crítico irredutível nos seus pontos de vista, equilibrado e preciso, embora marcado pelo vinco sentencioso de juiz, Veríssimo é uma das figuras mais autenticamente representativas dessa prosa ensaística. Isso apesar da elegância equívoca do seu estilo, das limitações que sofria a sensibilidade dele. fechada a tudo aquilo não se aparentasse diretamente com o espírito do crílico. Problemas amazónicos,

33 No entanto haviam eles de intluir de modo profunclo, por exemplo, o primeiro Araripe Júnior, que mais tarde desenvolveria em sentido seu, as ickéias de intransigente brasilidade bebidas nos colaboradores da "Minerva Brasiliense" e da "Revisıa Popular" E que cle difundirá dando-lhe o necessário vezo pxicológico e estético maderno em diferentes graus desde a primitiva posiçáo dele, tomada com a "Carta subre a Literatura Brasilica", cle 1869. 
literatura brasileira e estrangeira, educação nacional, divulgação de idéias, expansāo da cultura tudo isso estuda e versa com rara honestidade, com certeira, profunda intuição crítica.

O itinerário das ciências para a arte, contudo, não será seguido sempre. Definidas vocações ensaísticas, tais como Capistrano de Abreu, Lafayette Rodrigues Pereira, Joaquim Nabuco, Clóvis Beviláqua, Rui Barbosa, embora sempre atentas à forma e à atividade literárias, tomam em compensação, outros rumos: a Historia, a Política, o Direito, a Sociologia. Nesta linhagem de ensaístas especializados nos seus campos próprios, mas servidos de notável expressão literária, encartar-se-ão ainda um Oliveira Lima, um Euclides da Cunha, mais tarde um Oliveira Viana, um Gilberto Freyre, um Otávio Tarquínio de Sousa: antes de tudo homens de letras, escritores; depois especialistas das suas matérias.

\section{PROBLEMAS DA "ARTE DE ESCREVER"}

No sentido de estabelecer um apuro idiomático, fruto de ideais parnasianos que agora reagem contra o desalinho romântico, o ensaio no Brasil tenta reformular a sua expressão. Coincide isso na prática com as atitudes agressivas de um magistério lusitanizante cheio de impertinência, em que Camilo é a figura mais considerável e José de Castilho a mais mesquinha. Certo sentimento de inferioridade brasileiro em relação às crfticas de desconhecimento e emprego incorreto da língua pátria, de deturpação deformante da linguagem a língua mestiça de atenienses - encontra apoio no geral preconceito cientificista do tempo, todo voltado para regras e contrarregras. Mas se por um lado provoca reações violentas contra este ponto de vista, estimula também o estudo e a prática erudita do idioma que éramos acusados de deformar e mutilar. Fazendo que então nos extrememos em exageros puristas, prova inconteste da nossa injustiçada superioridade vernácula, essa atitude favoreceria em breve a dilatada ditadura dos gramáticos. Em momento de comum acatamento pela Norma, o ideal da correção pregado pelos codificadores parnasianos iria curiosamente completar-se com o espírito ornamental implícito ao "escrever artístico". A procura do vocábulo raro funde-se então com a preocupação gramatical e a pesquisa do dicionário (onde aliás se encontram providenciais corroborações dos autores de monta) com o cultivo dos clássicos nos próprios textos ${ }^{(\mathbf{n})}$.

\section{PURISMO, TRADIÇÃO E TRANSIÇÃO}

Cumpre lembrar ao lado disso que as grandes presenças porluguesas na nossa imprensa Eça de Queirós, Ramalho Ortigão, João Chagas, 

(17):9-54, 1989.

Fialho de Almeida - confirmavam um ideal estilístico se nāo ortodoxamente lusitanizante (e tanto assim Rui vai reprochar na Réplica a francesia de Eça), conservando sempre a marca inconteste da prosa de além-mar. As virtudes da língua antiga coincidem com o favor lieerário neo-romantico da arqueologia, com a ressurreiçăo estetizante do passado, indispensável aos raros.

Desta forma a revalorização, na belle époque brasileira, dos escritores "clássicos", Vieira à frente, que aqui se procurava ostensivamente cultuar ainda melhor que o berço nativo, coincide com o sentido cinzelador da literatura decadente, invejada vanguarda artística européia, e que provoca curiosas repercussōes no ensaio da época. Algumas dessas preocupaçōes estilísticas extremar-se-ão em excessos ornamentais, desaguando no rebuscado amaneiramento de muitas estéticas pessoais do tempo. Estão nesse caso o incessante cromatismo de Raul Pompéia, afiliado às raretés goncourtianas, a riqueza vocabular of uscadora de Coelho Neto, a precisão e o rigor arcaizantes de Rui e de Laet, o texto técnico e singular na frase larga, compósita, já de si ondulante, de Euclides. Soluções diversas, mas aparentadas às suas, vamos encontrar em autores tais como Alcides Maia, Alberto Rangel, Monteiro Lobato, Graça Aranha. Furungadores de dicionários, esses "estilistas" (quase todos eles assinando suculentas páginas de ficção) já foram apontados como aquela "familia dos farfalhantes" ${ }^{34}$ que identifica a realização literária ao luxo do estilo.

\section{GREGOS E TROIANOS}

Mas é preciso não esquecer ao lado desses "asiáticos", perfilhados a uma Ásia tantas vezes menor, que o ideal de aticidade náo desaparece da prosa de ensaio; muito pelo contrário. Avessos à rapina de vocabulário e construções imponentes, para esses cultores da medida e da contenção urbana o manuseio dos escritores antigos consistirá mais na coleta impregnada de ironia desta locução ou daquela regéncia, de um ou de outro modo de dizer sugestivo que renovem com sutileza a língua contemporanea, comunicando-lhe discreto sabor acre. Mestre insuperável no genero, Machado de Assis contará com seguidores dessa vertente num Constancio Alves ou num Domício da Gama, e, de modo mais limitado, nos humoristas no genero de Martim Francisco e Mario Brant, de Leo Vaz e Godofredo Rangel. Outros que refogem seja o torneamento generoso dos farfalhantes, seja a discreção excessiva dos áticos, preferem a fluência romantica, eloqüente, grandiosa, de um Renan, 
(17):9-54, 1989.

nesse tempo em que o ritmo da língua francesa flui sugestivo para todas as sensibilidades letradas.

Ao seu lado ainda, a experiência simbolista experimenta a prosa poética, da crônica evocativa ao poema em prosa. A revolução branca do "nefelibatismo" não se resumiu apenas ao alargamento (com a correspondente retração) de um vocabulário escolástico específico. Tanto o ritmo como a estrutura da frase foram experimentados nas suas possibilidades virtuais, e tempos depois retomadas com éxito. E no campo da crítica contou com Nestor Vítor, divulgador do jornalismo de ensaio com larga experiência de autores pouco ou nada freqüentados pelos grupos dominantes.

\section{ENSAÍSMO, ARTICULISMO}

Existindo de modo fundamental nas folhas, e só em segunda instancia nas revistas, conforme já se viu, o ensalsmo tem de tomar a forma obrigatória de colaboração para a imprensa. Sinonimos imperfeitos, articulismo e ensaísmo são obrigados a coincidir de todo nas condições culturais do Brasil; as exceções pertencerão sempre a um campo definido História das Idéias, Sociologia da Cultura, Filosofia do Direito. Daí a importåncia das seçōes fixas ou da colaboração constante em jornais e revistas, coletadas mais tarde em volume. Casos como o de Carlos de Laet e Constâncio Alves que com cinqüenta anos de ininterrupta colaboração de grande qualidade literária na imprensa, são ainda assim praticamente ensaístas sem livros -, falam por si sós bastante alto para configurar essa peculiar situação. Muito mais corrente em nossa literatura pode parecer ao primeiro momento, e por isso aceita como irremediável, o universal da prática fez com que o articulismo de ensaio fosse com o tempo considerado a forma mesma da expressão do gênero, votando a uma irrecorrivel efemeridade mesmo aquilo que de mais importante pudesse aparecer debaixo dessa forma. Sem ter sido o único, Sílvio Romero foi o ensaísta que de maneira mais veemente se recusou a esse fragmentarismo consagrado, preferindo seccionar, revistas e folhas afora, seus estudos quase todos eles de dimensōes ponderáveis.

O caminho natural dessa produção, mesmo quando as dimensões do escrito pediam edição em volume, era a imprensa periódica. Mas como "neste nosso Brasil é infinitamente mais considerável a quantidade de pessoas que leem jornais do que a das que abrem livros"35, seriam exatamente estes papéis volantes os impressos que atingiam um público mais amplo. Bem verdade é que depois de lidos e comentados tomavam rumo do fogueteiro; 

(17):9-54, 1989.

contudo, muitas vezes eram colecionados também nas amplas casas de antigamente, e serviam de leitura a duas e três geraçōes.

\section{ÚLTIMOS ORADORES}

Parece datar deste período o declínio da oratória parlamentar e polf́tica de significação literária, até então exercendo imensa influéncia em toda a sociedade. "Mas - escreve Fernando de Azevedo toda essa eloqüencia a que o Romantismo emprestara proporções grandiosas, quase espetaculares, e com a qual o Parlamento se tornou no Império "a forja de nossas letras", já vinha sendo ameaçada, pelo fim do século, no seu antigo prestígio, pela corrente das idéias filosóficas e cientificas com que se encerrava o ciclo romantico e se abriam perspectivas para uma nova percepção, realista, da vida e do mundo" ${ }^{36} \mathrm{O}$ sermão, como forma oral do ensaio, muito valorizado no seu aspecto cívico, sofrerá uma derradeira metamorfose na "conferência literária" de 1900, a última encarnação (ao lado da oratória de Rui, de impostação ainda imperial) do bem falar sermonístico ${ }^{37}$

\section{REVISTAS, QUASE SEMPRE}

Uma circunstância histórica, a queda da Monarquia, exigindo tanto de vitoriosos como de vencidos um esforço de análise do presente e do passado como até então não fora tentado, dera margem à afirmação de algumas das nossas melhores vocações ensaísticas, muitas delas até então realizadas

36 A Cultura Brasileira, volume II, p. 106. Sáo Paulo, Melhoramentus, s.d.

37 A posiç̧̧o de Nabuco e Rul e curiosamente simétrica quando se pensa no lugar que ocupam como oradores polltioos de "altn" expressão literíria, e que mesmo escrevendo não perdem de modo nenhum a sua redoncin eloyuencia de bem-falantes. Ocupando nas Camaras republicanas - lugar delxado vago por Nabuco, Rui tentará inutilmente prolongar no novo regime o prestigio literário do Parlamento imperial. Excelente motivo para ser mal visto, pols conforme assinala ainda Fernando de Azevedo: "As letras, a que o regime parlamentar do Imperto imprimira um notável relevo e quase um valor prático, utilizando-as como um dos instrumentos de açáo pollilica e social, tornavam-se por essa forma na Republica, ańo só estranhas, mas suspeitas a politicn, dominada pelo imediatismo utilitírio o afognda nas questóes militares e nas agitaçoes partldários" (A Cultura Brasileira, cil., volume 11, p. 107). Ers o declinlo final da influencia din iribuna, pimeiro religiosa, depois civil, e do pecultar ensaismo oral condicionado por ela, que tanto prestigio gozou e tantn influêncin exerceu entre nós. 

(17):9-54, 1989.

apenas parcialmente ${ }^{38}$ A passagem do novo século, vindo repor o balanço das atividades intelectuais do País, encontrou assim a nossa intelectualidade definitivamente dividida entre nacionalismo e cosmopolitismo.

\section{DISCUSSŌES}

A primeira década republicana, com os naturais desajustes que a mudança de regime acarretara à Nação, havia exigido de todo o Brasil pensante uma imediata tomada de posição diante de nossas coisas. Até então desconhecidas senão de uns poucos estudiosos isolados, a problemática brasileira passa a ser discutida não só do prisma político, mas notadamente social. Dentro da concepção alemanista da "Escola de Recife" os caminhos da cullura são compreensivos, encampando, com grande elasticidade, todas as manifestaçōes do pensamento nacional. O grande doutrinamento que a obra de Sílvio Romero representa parece influir de modo indire to sobre quase toda a prosa de ensaio do tempo, marcando, com a extrema exacerbação característica dele, construtiva e polêmica, o comum interesse pelo estudo da nossa realidade.

Mas sejam prosadores ligados a Tobias e a Romero (Artur Orlando, Sousa Bandeira, Graça Aranha), sejam independentes (Eduardo Prado, Euclides da Cunha, Oliveira Lima), esses e mais outros continuam e completama obra em comum encetada pela "Revista Brasileira" da segunda e terceira épocas, e que se tentou consolidar com a instituição da Academia de Letras.

\section{UMA CAPITAL CIVILIZADA}

Esse criticismo compreensivo dava margem ao expandir-se, de um outro lado, da realidade meramente urbana da grande cidade: o desenfreadoe ingênuo cosmopolitismo mundano do Rio, que atravessa um segundo e frenético civilizar-se.

O Rio civiliza-se! é a frase feita célebre para caracterizar a remodelação material dos costumes e da sociedade carioca. O grande cronista desse momento de inquie tação superficial será Paulo Barreto. Como pseudônimo coerente de Joāo do Rio ele quer significar a sua intimidade com a Cidade que se

38 Demasiado conhecidus e glosados os casos de Nabuco e Eduardo Prado, o primeiro renlizando a purte mais substanciosa da sua obra quando no osiracismo voluntírio a que se voltou "os dez anos de luto pela Monarquia"; Prado entregando-se ao jornalismo de panfleto e de ensaio em que se realizou de modo quase definitivo com ngudo sentido dos valores perenes. 
enfeita de tentacular, atingida também ela pelas taras moderníssimas das grandes capitais européias.

Escritor de talento, a se dispersar numa literatura mais do que apressada se desejando vertiginosa, dono de um estilo que à primeira abordagem aparece construfdo apenas com os tiques e os cacoetes da moda, ele representa, divertido, consciente, a caricatura de um determinado grupo em situação. Retrato ironicamente retocado do art nouveau carioca - de que P. Lopes será o mais lídimo representante, mas numa dimensão ideal e quase angélica que afinal o aparenta a um Rousseau le Douanier -, árbitro das elegáncias intelectuais da época, além das muitas fórmulas que soube manusear como ninguém, foi escritor capaz de nos deixar uma Alma encantadora das ruas, ensaio descritivo de psicologia urbana que é pouco menos do que uma obra prima.

No seu estilo compósito e funambulesco, esse cronista que não conseguia a fluência serena de Bilac sucessor ao mesmo tempo de Eça e Machado - nem a graça espontanea Artur Azevedo, que continuava o humanismo digerfvel de França Junior, resumiu com aguda vivacidade, resumiu com malícia insuperável, um mito de que foi, afinal, o principal ator. Proust de um mundanismo sem aristocracia, em que Dona Laurinha dos Santos Lobo foi ao mesmo tempo Mme. de Guermantes e Mme. Verdurin, mais do que ninguém ajudou a criar uma ilusåo nacional de esnobismo up-to-date, do qual foi o melancólico repórter e o ironista de gênio.

\section{"A ERA DAS CONFERENCIAS"}

Ao lado da crônica e da reportagem ${ }^{39}$ é cultivado também um outro gênero menor que, se gozara de algum prestígio nos meados do século anterior, empolga do modo mais completo agora o público do tempo: a "conferência literária" Documentando, do ponto de vista dos costumes, uma exuberante vida social, esse tipo de oração para ser recitada em sociedade participa ainda do campo do ensaio. Um ensaio quase sempre frivolo, variaçáo palavrosa em torno de algum tema genérico, vago, efemero. Recolhidas em livros após serem recitadas aqui e all pelos autores (bem remune rados por esse trabalho, desde que as conferências são com entrada paga), representam fenómenoliterário inseparável do perfodo. Brito Broca propós com justeza que elas fossem inclufdas

39 "Com Joåo do Rio, na primeira década do século, n crónica-fothelim, do moxlelo de Machado de Assis, que já í perdendo o contorno clássioo com Bilnc, converle-se em reportagem. Ern uma surpreendente Inovaç̧io na épuca". Brito Broca: "Cronistns de Outrorn", recurte nfoo Identificado da "Gazela" de STro Paulo. 
EUL.ÁLIO, Alexandre. O ensaio literário no Brasil, Língua e Literatura, São Paulo, (17):9-54, 1989.

debaixo do designativo de "prosa parnasiana" que Otto Maria Carpeaux cunhara na Pequena Bibliografia C'ríticadaLiteraturaBrasileira ${ }^{40}$. Na verdade o gennero encartava-se do modo mais ortodoxo dentro da estética gratuita, ao mesmo tempo do conceito ornado e da frase alambicada, que as tornam autênticas peças em prosa correspondentes, pelo espirito, aos sonetos da escola: polidos, sensfveis, encantadores, vazios. Decorativos e incômodos como o febril bric-à-brac esmagador das casas de então.

\section{CONTUDO ALGUNS FRUTOS}

Mas nada de exageros, anota ainda Brito Broca. "É preciso considerar que apesar daquilo que podemos chamar a sua 'perversão", a moda trouxe algumas vantagens, concorrendo para que fossem escritos alguns dos bons livros da literatura brasileira" E prossegue "O primeiro estudo de conjunto da obra de Machado de Assis daf provém: resultou das palestras pronunciadas por Alfredo Pujol na Sociedade de Cultura Artística de São paulo, depois enfeixadas em volume. Tambem ali Afonso Arinos realizou um curso sobre lendas e tradições do Brasil, transformado em livro. Umas das mulheres obras em prosa de Bilac são as ConferênciasLiterárias, nas quais encontramos a famosa exaltação de Dom Quixote, o estudo sobre Gonçalves Dias. E a conferência de Gilberto Amado, no salão do "Jornal do Comércio", a 9 de agosto de 1913 sobre o tema "A Chave de Salomão", legou-nos uma das páginas mais notáveis das nossas letras. Sem falar na série promovida por Manuel Cícero Peregrino em 1912, na Biblioteca Nacional ${ }^{41 "}$ Com os seus lados contraditórios, foi tal a voga no género que os próprios ironistas que o satirizam será o caso de João do Rio nem por isso delxam de o praticar.

40 "Nåo seria demais ver nas 'conferências literńrias', nos moldes aludidos, uma expressáo tfpion e Irlunfante dessa prosa. Faziam-se elas com material semelhante no dos sonetos parnasianos, havia identidade de vocabulário entre uma e outras. Basta ver os tifulos 'O Mnr', 'O Espelho'. 'A Tentaç̧o' (Oscar Lopes: Três Conferencias) 'A Mulher' (Oarcia Redondo: Conferências), que o sâo também de sonetos parnasianos". Em "A conferência literária e a prosa parnasiana". Recorte sem indicaç⿰丿乛⿱㇒⿵冂卄丷 de "A Gazeta" de Shro Paulo. O lexto fol reescrito e desenvolvido à p. 139 de A Vida Literária no Brasil 1900. $2^{\circ} \mathrm{ed}$. As observagóes de Carpeaux sobre a prosa parnasiana Integram a p. 162 de $2^{\prime}$ ediçto da Pequena Bibliografia Brasileira da Literatura Critica. Rlo de Janeiro. Servlço de Documentaçî́o do MEC, 1955. 


\section{OUTRAS PRESENÇAS}

Mas Joāo do Rio evidentemente não é o único figurante desse período contraditório. Os anos que precedem de pouco à Grande Guerra encontrarão além das vocaçōes algo dispersivas que se dividem indiferentemente entre ficção e ensaio, e de que entre os menos idosos Alcides Maia e Xavier Marques são exemplos, os pendores fundamentalmente ensalsticos de Gilberto Amado e António Torres. Diversos entre eles, como o são, resumem a inquietude mental dessa época. O primeiro todo voltado para problemas gerais, propostos numa prosa vibrante, dominada de modo muito seu pela ineludível vocação pedagógica de líder intelectual. $O$ segundo, realizando-se na fluência elegante e segura de um escrever aprimorado, a se interessar pelos aspectos peculiares do dia-a-dia, a sua vocação de moralista modulada mais por um vago ideal de bom-senso e de equilíbrio primordiais, quase sempre levados à deriva pelo temperamento passional do autor.

\section{TORRES \& AMADO}

Paralelos, os ensaísmos de Torres e Amado completam-se em distintas áreas de inconformismo e espírito revisionista. $O$ segundo circunscrevendo o primeiro, atravessarão toda a década de 20 como figuras das mais representativas do gênero. Um no terreno das idéias literárias e políticas, outro no da sátira dos costumes e da atualidade jornalística. Ambos inequivocamente prolongando, no espírito belle époque que presidira a formação deste e daquele, os aspectos mais vivos e ardentes do revisionismo nacional que também se reflete de outro modo na "Revista do Brasil" de Monteiro Lobato. Deste modo a formação liberal de Gilberto Amado na Faculdade do Recife, e a eclesiástica de Torres, no Scminário de Diamantina, completavam-se antiteticamente em meio ao cenário das letras do 1900 brasileiro nesse meio em que o Modernismo heróico representa como que o efervescente precipitado final, encerrando complicado processo químico realizado em cadeia.

\section{UMA VONTADE DE CULTURA NACIONAL}

Também a "Revista do Brasil, sob a direção de Monteiro Lobato, e em certo período também Paulo Prado, representará de modo todo panorâmico a mentalidade brasileira profundamente insatisfeita com a realidade presente, pretendendo agir de modo concreto pelo menos dentro do campo cultural. Em luta contra todas as formas de espírito estagnado, não lhe repugna a colaboração das figuras independentes das gerações anteriores. Um João Ribeiro, 
(17):9-54, 1989.

um Martim Francisco, um Amadeu Amaral, um Nestor Vítor, um Alberto Faria, díscolos na geral arregimentação dos grupos estético-ideológicos, terão entrada franca na revista. Todos os talentos autênticos são af acolhidos. Durante os dez anos de existéncia da revista, de 1916 a 1925, ela dará guarida a gregos e troianos, inclusive aos primeiros modernistas.

\section{OS DE ENTÃO}

Afrânio Peixoto, Humberto de Campos, Jackson de Figueiredo, Ronald de Carvalho, Tristão de Ataíde, Sud Menucci, Plínio Barreto, José Maria Belo, Fernando de Azevedo, destacam-se na prosa de não-ficção deste período, em que continuam a produzir alguns dos grandes nomes que vêm do Segundo Reinado ou dos primórdios da República, que sobreviveram aos contemporaneos: Laet, Neto; Afonso Celso; Constâncio Alves; Medeiros e Albuquerque. Ensaístas diferentemente motivados, tendendo para a erudição pura, para o combate ideológico, para a crítica estética, sociológica ou sincrética, esse período que os contém a todos é dos mais fecundos para o gênero. O espírito essencialmente analítico e judicativo da época propicia um geral estabelecimento de critérios de apreciação da realidade, nas mais diversas áreas. Há alguma coisa no ar que ninguém pode dizer exatamente o que seja.

\section{O ESTOURO}

O Modernismo sucederá de pouco ao aparecimento da "Revista do Brasil", e de maneira diferente dela busca uma reforma radical da literatura, ainda então praticada sob a égide da sensibilidade finissecular, representa ainda o mesmo estado de espírito de redescoberta do Brasil.

Neo-romantismo cujas brigadas de choque entraráo violentamente em cena, viria receber a adesảo de um Ronald de Carvalho e de um Graça Aranha a simpatia irônica de um João Ribeiro, a compreensão defensiva de um Tristão de Ataíde. Com os restantes polemicaria quase sem tréguas até a década de $\mathbf{3 0}$.

\section{PROBLEMAS DE EXPRESSÃO}

Encontrando entre os escritores jovens alheios ao movimento uma prosa amadurecida e cheia de recursos que segue determinados ideais, a 
oposição estillistica e artesanal dos "futuristas" - Oswald de Andrade, Mário de Andrade, Antônio de Alcantara Machado - será muito fecunda no sentido de síntese que irão realizar, à procura de um discurso ricamente plástico, que vai se aproveitar das novas conquistas mas não deixará de utilizar a tradição.

Assim à prosa protestante, aforística, subjetivista, de um estilo às vezes telegráfico, de que Oswald e Mário de Andrade dão a senha, e Antônio de Alcântara Machado resolverá numa dimensão própria, inimitável, vai suceder uma busca de equilibrio expositivo e estético na qual tanto aqueles diretamente ligados ao movimento, como aqueles que se desenvolvam à margem do debate estético, acabam por se beneficiar. Pedro Dantas, Sérgio Buarque de Holanda, Rodrigo M. F. de Andrade, Manuel Bandeira, Sérgio Milliet por um lado; Gilberto Freyre, Paulo Prado, Tasso da Silveira, Andrade Murici; Agripino Grieco; Fernando de Azevedo; Luís Delgado, Eduardo Frieiro, Olívio Montenegro, Otávio Tarquínio do outro lado representam, grosso modo, as posições principais em torno do ensaio crítico, interpretativo ou expositivo, e que transitam, dentro de distintas categorias de experimentação, para um pós-modernismo em que voltará a prevalecer o ideal da prosa equilibrada.

\section{MODERNISMO E ESTILO}

São sem número os problemas e contradições dessa prosa ensaística - da qual não estamos fazendo a história mas apenas tentando esboçar o evolver através do século e meio de consciente vida literária nacional. Procurando ao mesmo tempo as possibilidades do "estilo moderno" como as do chamado "académico", um grupo deveras excepcional de ensaístas levará conscientemente esse falso dilema a uma superaçāo resolvida com o amadurecimento estético de cada artista, e a posterior depuração vocacional. $O$ caso da prosa de Mário de Andrade; da prosa de ficçāo como da de ensaio, fornece o mais expressivo exemplo do que se pretendeu dizer: ela caminha da sua primitiva vontade de um formulado maneirismo, para a fluência larga e pessoal do seu último escrever. Soluções igualmente pessoais, como a da cadéncia frasística de Gilberto Freyre, largamente enumerativa e dividindo-se em sub-orações independentes, adequadas à maravilha aos seus inventários proustianos, se se tornam irresistíveis aos imitadores, são impossíveis de serem transmitidas a mais ninguém. Os epigonos vêem-se na ominosa condição de pasticharem o mestre.

O "Boletim de Ariel" é o marco simbólico que anuncia uma nova geração de ensaístas, esta verdadeiramente notável. Lucia Miguel Pereira , Augusto Meyer, Eugênio Gomes, Astrojildo Pereira, Afonso Arinos Sobrinho, Barreto Filho, Carlos Dante de Morais, Aires da Mata Machado Filho, Moisés Velinho. A ela se juntará pouco depois a de Álvaro Lins, Viana Moog, Cristiano Martins, Otto Maria Carpeaux (que a guerra e o exílio tornam escritor brasileiro), Afranio Coutinho, Brito Broca, Temístocles Linhares, Adonias Filho, Aurélio 
(17):9-54, 1989.

Buarque de Holanda, Gustavo Corção. Todos eles, sem excetuar quase nenhum, prosadores que irão preferir como seu meio de expressão uma prosa tersa, quase neoclássica na sua maneira de ser discreta, à qual se pede, antes de mais nada, interfira o menos possível no jogo abstrato das idéias, e seja antes de tudo plástica e expressiva.

\section{A TRADIÇĀO DA CRÓNICA}

Único gênero, conforme já se fez notar, que acompanha o gosto do público sem perder a qualidade literária, - e, ao contrário, em cada situação nova recria essa qualidade -, a tradição brasileira do familiar essey persistia muito viva depois de João do Rio. Raimundo Correia, Guimarães Passos, Artur Azevedo, Coelho Neto, nomes exponenciais na poesia e na prosa desse tempo, haviam-no cultivado até a época da morte de cada um deles - a de Coelho Neto ocorrida dez anos após a de Paulo Barreto. Mas se eram cronistas à maneira tradicional, contando com público certo, não acompanhavam de modo nenhum a inovação da reportagem lírica, essa grande contribuição de João do Rio ao gênero, já então algo estafado.

Por essa época começa a crônica a evoluir a pouco e pouco para a forma que tomará em nossos dias. "Processou-se a transição gradativamente, de modo quase imperceptível, como cresce na natureza aquilo a que a força vital dá alento" - escreve Vivaldo Coaraci ${ }^{42}$ "Nem por isso foram menos profundas e acentuadas as transformaçōes. E a cronica assumiu novo aspecto e consistência, adquirindo, independente e livre, os foros de gênero literário definido e genuíno. Libertou-se o cronista das algemas da atualidade, proclamou-se independente da contingência do comentário oportuno ao "caso do dia". Em vez de procurar assunto no noticiário, passou a buscar inspiraçāo nas impressōes quaisquer recolhidas pelo seu espírito através da observação, da fantasia ou da reflexão" E conclui Coaraci com finura: "Deixa de ser jornalista para se tornar escritor; troca ${ }_{43} 0$ ofício pela arte, aceitando todas as suas responsabilidades e exigencias" ${ }^{43}$

\section{A CONTINUIDADE}

O disputado bastão de cronista seria passado adiante, nesse período de busca, ora por um Lima Barreto (cujo profundo ressentimento social fará dele, ao lado de Torres, o mais ferino dos comentaristas); ora para o curioso

42 "A C'rônica", em 91 crônicass escolhidas, p. XV, cilt.

43 Ibidem. 

(17):9-54, 1989.

diletantismo do segundo José do Patrocínio; ora ainda para o cosmopolitismo mais ou menos mundano de um Theo Filho ou de um Tomás Lopes; ora para a vacilante fluência de um Humberto de Campos.

E assim o genero não sofre mutações profundas com o costumismo sentimental da geração seguinte, Ribeiro Couto, Manuel Bandeira, Peregrino Júnior, Vivaldo Coaraci, Álvaro Moreira, autores de algumas páginas definitivas no gênero. Nem com eles, nem com o experimentalismo modernista, (pois com Mário de Andrade e Antônio de Alcântara Machado são tentadas diferentes soluções para o gênero) a crônica sofre transformações essenciais. Sem nenhum caráter urgente estas serão propostas no entanto por um Rubem Braga, renovador do gênero, que aproveita do modo mais pessoal algumas sugestôes intimistas já esboçadas tanto pelo poema em prosa dos anos 10 e 20 , como pelo penumbrismo sentimental à Ribeiro Couto, reformando-os com o raro sentimento íntimo do coloquial e do cotidiano mágico.

\section{BALANÇO CRONIQUEIRO}

A passagem da objetividade primitiva para um subjetivismo lírico mais ou menos radical corresponde a uma autêntica revolução nesse processo de focalizar a realidade. Isto é, uma revisão do gênero que toca nos seus próprios fundamentos.

Próximo da poesia pelas muitas possibilidades do flagrante lírico, a mudança do ponto de vista exterior do cronista para o interior do sujeito, enriquecendo infinitamente as possibilidades do flagrante humano, depois de Manuel Bandeira voltou a tentar alguns dos maiores poetas do País, como Carlos Drumond de Andrade e Cecília Meireles, assim como outros mais jovens, como Ledo Ivo e Paulo Mendes Campos, e a ficcionistas como José Lins do Rego e Fernando Sabino. Hoje é sem dúvida o gênero mais popular do País, o único a manter um contacto direto e cotidiano com o leitor através da imprensa.

\section{DO ENSAIO REMEMORATIVO}

O memorialismo assume uma posição especial dentro do campo do ensaio estético apenas quando ele aí realiza uma prosa que de modo consciente combine narrativo, descritivo e interpretativo. Descendendo por um lado do ensaio personalista de Montaigne, cuja marca é visivel em toda a tradição intimista do genero - as Recollections of Childhood de Steele, são um sinal da sua continuidade em pleno Século XVIII -, a autobiografia alcançaria o apogeu durante o Romantismo. "Era natural que numa época menos voltada para os problemas de casuística, mas preocupada, pelo contrário, em registrar o 
nuançamento da própria sensibilidade (como é o caso do período romântico) escreve Mário Praz o ensaio devesse transformar-se num insırumento, o mais ágil e o mais eficaz, da autobiografia. O Romantismo descobriu a autobiografia interpretando-a não no sentido de vida exemplar, mas de apaixonante documento humano" - continua o crítico de Il Romanticismo. "O criador do ensaio autobiográfico moderno foi Charles Lamb, num grupo de composições (Recollections of ('hrist Hospital, Dream Children, Old China) em que o ensalsta pode ser definido como um lírico em prosa, preocupado em fixar certo ritmo demasiado sutil para o verso, e vivaz como o tagarelar de uma conversação" ${ }^{44}$

No Brasil, o memorialismo de categoria literária aparece tardiamente. Era natural que assim fosse numa cultura de formação recente, pouco afeita aos lazeres da rememoração. Assim, até o presente, o gênero existe entre nós do modo mais fragmentário e ocasional.

Cumpre-nos, antes de mais nada colocar num segundo plano aquelas obras desta família que, ainda possuindo emoção, importam mais pelo seu conteúdo informativo do que pela contextura estética. Sejam elas escritas por coetâneos ilustres como as Minhas recordaçöes, de Ferreira de Resende, as Reminiscências da Campanha do Paraguai, de Dionísio Cerqueira, ou as Coisas do meu tempo, de Ernesto Matoso. Ou sejam obra de homens de letras, diferenles entre si como Taunay, Oliveira Lima, Medeiros e Albuquerque, Humberto de Campos, todos eles autores de Memórias.

Entretanto, ainda que fragmentários e esparsos, já são peças de nível homogêneo o Como e porque sou romancista, de Alencar, $O$ Velho Senado, de Machado de Assis, Cousas do meu tempo, de Salvador de Mendonça, Horas do bom tempo, de Lúcio de Mendonça, Minhas memórias dos outros, de Rodrigo Otávio, o malogrado $O$ meu próprio romance, de Graça Aranha, para só citar algumas.

O caso de Nabuco e de Minha Formação o mais intrinsecamente ensalstico de todo o nosso memorialismo, no sentido de ser análise compreensiva e intelectualizada de uma vida cheia de plenitude , inauguraria linhagem tão respeitável quando escassa em nossas letras. Se não pode ser continuada, conforme parecia lógico, pela me mórias de Graça Aranha, interrompidas pela morte, encontraria ela na exuberante rememoraçáo de Gilberto Amado um livre prolongamento da sua maneira, no mesmo tempo intelectiva e comovida. Dois poetas bastante diversos, Manuel Bandeira e Augusto Frederico Schmidt, parecem entrosar-se nessa família de rememoradores: o autor de $O$ Galo Branco por uma certa qualidade maciça de 
(17):9-54, 1989.

sua prosa, curiosamente aparentada com a de Nabuco pelo torneio sensual; a do autor de Itinerário de Pasárgada, pela diferente capacidade e lucidez no compor uma biographia litteraria (agora no sentido mais exclusivamente coleridgiano de belas-letras), idéntica à de Nabuco pela riqueza da seiva humana e pela elegancia formal e intelectual.

\section{ALGUNS SIMPLES EXEMPLOS}

Já o memorialismo de Graciliano Ramos, e também o de Oswald de Andrade e o de José Lins de Rego, tendem para uma narração que se cre e se quer fielmente objetiva tanto ao autor como à realidade circunstante. Enquanto que já pertencem ao território das mais legítimas "memórias sentimentais" as de Augusto Meyer (Segredos da Infáncia) e Ciro dos Anjos (Explorações no Tempo). Estes últimos, autênticos "líricos em prosa", entregam-se de modo voluntariamente estético aos jogos recorrentes da rememoração. Construindo uma língua sutil e cheia de tonalidade, encontram naquele mesmo sereno rigor o estilo conciso do autor de Infancia e Memórias do Cárcere.

Idéntica a toda e qualquer literatura recente, a nossa não podia constar neste campo senão com diminuta produção de valor propriamentente estético. Mas só o fato do genero continuar a ser versado no presente, e contar com diversas outras obras de valor na década de 50-60 (de que nāo trata este resumo) indica que o memorialismo de categoria intrinsecamente literária caminha para ocupar dentro do ensaísmo brasileiro um lugar dos mais decisivos.

\section{PRESENÇA E PREMENCIA DO ENSAIO}

Esse geral renascimento do ensaio abaixo de todas as suas formas é como que simultaneo à criação das primeiras faculdades de letras. $O$ encaminhamento para a cultura universitária começa a fazer que o gênero se apresente como problema estético e cultural. Começando a delxar o caráter intuitivo de filho ocasional da imprensa, que de modo genérico teve entre nós, ele chega à hierarquização das diversas calegorias do gennero, do articulismo 

(17):9-54, 1989.

jornalístico ao ensaísmo propriamente dito. Parecíamos ter chegado ao limite de consciencia indispensável para a plenitude dessa espécie literária

Para isso concorreu a crítica cheia de maturidade exercida por um Tristão de Atáde, um Mário de Andrade, um Álvaro Lins, um Antonio Candido, este talvez o primeiro elemento formado pelas novéis faculdades de letras a ocupar um lugar destacado em nosso ensaísmo. Como o presente trabalho encerra-se voluntariamente em 1950 portanto no limiar da carreira de vários nomes dez anos depois de prestígio nacional - v.g. M. Cavalcanti Proença, Wilson Martins, Décio de Almeida Prado, Fausto Cunha, Sábato Magaldi, etc. encerramos nossa resenha num momento como esse, de inequívoca ascensão ensaística, quando começam a se delinear várias novas tendéncias do gênero.

45 Os grupos culturais que a província reáne, dentro da instabilidade que lhe é própria - o "Parnaso Maranbense", a "Escola de Recife", a "Padaria Espiritual", "A Mina", os simbolistas de Curitiba so poderiam ganbar conteúdo real e efetiva consistencia após a criaçấ das universidades regionais, fundadas depois de 1930. Até essa data entra o acaso de mocko decisivo na sua

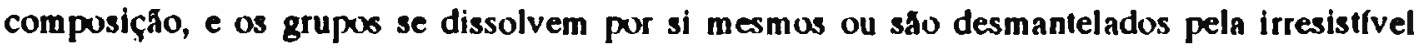
atraçăo que a Capital exerce sobre os seus componentes de maior categoria. A este respeito muito características, pela quase total unanimidade, as respostas, no inquérito de Joáo do Rio sobre $O$ momento liserhíio, ao quesito respeitante As entáo chamadas (quase sempre com ironia) de "literaturas estatuais". Dal podermos dizer sem nemhum exagero que Regionalismo consciente adotado como atitude ética e estética, entre nós só consegue realmente nâo apenas existência, mas real motivaçáo, a partir do estabelecimento de Gilberto Freyre no Recife ${ }^{(0)}$. A exposição da sua ideologia coerente vem proposta no Manifesto dito de 1926. Cumpre nutar, contudo, que a proliferaçåo das Academias de Letras provinciais nas duas primeiras décadas do presente século ja indicava o compreender, acanhado que fosse, da idéla e do sentido de "regifo c tradiçấ" Se nos Estados mais subdesenvolvidos representam mimetismo desprovido de melhor sentido da realidade em provincias mais progressistas coincide com o crescimento e uma ilusória consolidaçăo do novo espirito federalista, seu reflexo no campo político exprime-se de maneira tado poderosa e mesquinha com a polftica "dos governadores" ${ }^{(p)}$. Seria talvez o caso da Academia Mineira, significativamente fundada no ano de $1812 \mathrm{em}$ Juiz de Fora - na "Manchester mineira" e náo em alguma das várias Atenas ou Coimbras provinciais. E que se transfere pouco depois para Belo Horizonte, apos ter-se a "Cidade de Minas" firmado de vez como centro de inconteste prestlgio polltico e economico. Tambem o novo essor contemporaneo da literatura gaúcha de Porto Alegre, baseado sem davida numa matizada tradiçáo local, coincide fora da menor dúvida com o desenvolvimento do Estndo, inclusive com a fundaçắo all, nos anos 20, de uma editora logo de importancia nacional. Exemplos a serem considerados, e clos mais expressivos, do problema da dicatumia cultural Corte-Província, no complexo nacional brasileiro, sáo ainda os grupos de Fortalezn no fim do seculo, ou o de Maceió entre 1925 e 1935: o ncaso e condiçöes especiais (inteligente meconato, bem estar relativo da classe media) parecem ter sido os motivos que possibilitaram a respectiva eclusáo. Mas somente o trabalho continuado e modesto da Universidade poderia levar adinnte esse esforço de autênticu enraizamento cultural. 

(17):9-54, 1989.

\section{CONCLUSĀO?}

Nascendo com a imprensa e até hoje vivendo em grande parte dela, um levantamente geral do ensaio literário brasileiro, de 1800 a 1950 , apresenta um saldo deveras positivo. A crônica, que é o nosso familiar essay, possui tradição de primeira ordem, cultivada, desde o amanhecer do periodismo nacional, pelos rnaiores poetas e prosistas da época - não será necessário citar aqui outros nomes além dos de José de Alencar, Machado de Assis, Carlos Drumond de Andrade. Seu vigor está comprovado ainda hoje pelos livros desse genero que sem cessar saem dos prelos: recolhendo produções dispersas pelas revistas e pelos jornais falam por si mesmos do real favor que gozam junto ao público.

O memorialismo, se até há pouco foi campo menos popular, depois de 1940 recebeu impulso fora do comum, tornando-se um daqueles mais cultivados pelos nossos escritores. De excepcional qualidade, algumas produções desse gênero já integram de modo definido a literatura brasileira. Entre descritivo, interpretativo e narrativo, pertencendo um pouco a cada uma dessas categorias, podemos juntar à autobiografia superiormente escrita aqueles ensaios que de modo parcelado descrevem, narram e interpretam, com sentido literário, a realidade intima brasileira. Pertencem a tal famflia ilustre Minha Formaçao, Segredos da Infáncia, Itinerário de Pasárgada, mas não deixam também de certo modo de dela participarem "memórias celetivas" no gênero de um Sobrados \& Mocambos embora de maneira menos metafórica participem elas mais propriamente da categoria seguinte.

Isto porque o ensaio crítico e interpretativo - tanto do fato literário específico, como aquele de idéias gerais, concebido num teor de prosa artística pode reivindicar a mais ilustre tradição. Num rol que seria ocioso repetir nesta última página, ele reúne os maiores nones das nossas letras. Realmente, todos os grandes cultores da prosa de não-ficção teriam de estar presentes a essa chamada geral. Basta que relacionemos, quase como homenagem, e um pouco ao acaso, alguns dos títulos fundamentais da nossa bibliografia: Os Sertões, História da Literatura Brasileira, Jornal de C'rítica, Retrato do Brasil, Ratzes do Brasil, Aspectos da Literatura Brasileira, Prata da C'asa, A Sombra da Estante, Dom João VI no Brasil, Casa Grande \& Senzala, Estudos de Literatura Brasileira, O Ocaso do Império, C'aṕtulos de História Colonial, A margem da História, A Cultura Brasileira, Um Estadista do Império, Interpretaçāo do Brasil...

Desta forma, podemos concluir tratar-se o ensaio uma das atividades mais ricas e complexas da literatura brasileira, malgrado possa parecer um primeiro momento uma província deserta, ou quase despovoada, das nossas 
letras. Voluntariamente incompleto, o resumo que aqui se encerra, - mera tentativa de visāo de conjunto do gênero - ele acredita realizado o seu fim se conseguiu lembrar ao leitor que, versado pelos melhores escritores, o ensaio afinal encerra a maioria das obras fundamentais da nossa cultura.

\section{APÊNDICE}

Notas, variantes e observaçōes marginais do autor.

a) El ensayo por José Edmundo Clemente. Buenos Aires, Ediciones Culturales Argentinas, 1961, p. 7.

b) Cuidado para não se deixar envolver apenas pela acepção "jornalística" ou "gazeteante" do ensaio. Ter sempre presente o ensaio como atitude para poder diferençá-lo logicamente de sua aparência formal (fôrma) p. ex. no sermão (peroração retórica). Daí a importância da atitude satírica.

c) Nota erudita sobre alguns exemplos que tais. Boa fonte: o Dicionário das literaturas portuguesa, brasileira e galega, vb. Prosa Doutrinal. gênero provocado por uma atitude; na antiguidade reinterpretado na atualidade; várias vertentes: tratadística (e exaustiva) - que terá reflexos, ou melhor, cujo corte espiritual repercutirá no ensaio erudito exaustivo, histórico, que vai nos interessar quando de confecção literária.

d) (Desenvolvível). O problema da prosa doutrinal na Lusitânia. Porque apesar de tudo é ensaística.

e) difuso, impreciso.

f) Ver Prado Coelho a respeito da influência de Bossuet e o "pregar francês". Nota a fazer: Embora, conforme anotou Jacinto do Prado Coelho.

ensaio/panfleto.

g) arrebatado.

h) Fazer levantamento organico do jornalismo de

i) Modificar aqui. Colocar mais precisamente o problema, fazendo a psicologia da sátira jornalística e ampliando com o jornalismo nacional da Independéncia, da chalaça ao humanismo.

j) ilustrado.

1) englobante.

m) (Cortado do original) data da estréia em livro de Romero, fundador da nossa critica sistemática.

n) Colocar o problema do Impressionismo. 

(17):9-54, 1989.

o) a tentativa de lastrear $o$ fato cultural em base antropológica.

p) - a ilusão do mecenato oficioso, da "literatura oficial" do tempo, letras e artes amparadas pela secretaria daqueles lúgubres palácios de governo art nouveau, em que quase sempre prevaleceu o que se pressupunha ser/tentava adivinhar como sendo a arte do governo - alegorias positivistas, livros patrióticos, civismo enfático (substitutivo republicano de um não menos desbragado aulicismo imperial) - evoluiriam para uma oposição franca a este oficialismo imóvel. 